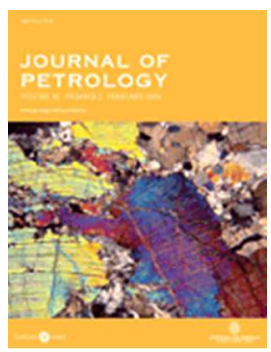

Draft Manuscript for Review

\title{
Controls of mantle potential temperature and lithospheric thickness on magmatism in the North Atlantic Igneous Province
}

\begin{tabular}{|r|l|}
\hline Journal: & Journal of Petrology \\
\hline Manuscript ID & JPET-Oct-15-0120.R1 \\
\hline Manuscript Type: & Original Manuscript \\
\hline Date Submitted by the Author: & n/a \\
\hline Complete List of Authors: & $\begin{array}{l}\text { Hole, Malcolm; University of Aberdeen, Geology \& Petroleum Geology } \\
\text { Millett, John; VBPR AS }\end{array}$ \\
\hline Keyword: & temperature, basalt, mantle plume, partial melting, P-T conditions \\
\hline & \\
\hline
\end{tabular}

SCHOLARONE

Manuscripts 
1 Controls of mantle potential temperature and lithospheric thickness on magmatism in the North Atlantic Igneous Province.

$$
\text { M. J. Hole }{ }^{1 *}, \text { J.M. Millett }{ }^{1,2}
$$

${ }^{1}$ Department of Geology \& Petroleum Geology University of Aberdeen, AB24 3UE, Scotland

$5 \quad 2$ Present address, VBPR AS, Forskningsparken, Gaustadalléen 21, N-0349 Oslo, Norway.

6 *Corresponding author

7 Modelled primary magma compositions of Palaeocene basalts from the North Atlantic

8 Igneous Province (NAIP) require melting at mantle potential temperatures $\left(T_{P}\right)$ in the range

$9 \quad 1480-1550^{\circ} \mathrm{C}$. Modern lavas from the Icelandic rift-zones required $\mathrm{T}_{\mathrm{P}} \sim 1500^{\circ} \mathrm{C}$ and those

10 from the rift-flanks $T_{\mathrm{P}} \sim 1450^{\circ} \mathrm{C}$. Secular cooling of the NAIP thermal anomaly was therefore

11 in the order of $\sim 50^{\circ} \mathrm{C}$ in $61 \mathrm{Ma}$. There were systematic variations in $\mathrm{T}_{\mathrm{P}}$ of $50-100^{\circ} \mathrm{C}$ from

12 centre of the thermal anomaly to its margins at any one time, although limits on the

13 stratigraphical distribution of $\mathrm{T}_{\mathrm{P}}$ determinations do not rule out thermal pulsing on a

14 timescale of millions of years. Variation in extent of melting at similar $\mathrm{T}_{\mathrm{P}}$ was controlled by

15 local variability in lithospheric thickness. In the west of the NAIP, lithosphere varied from

$16 \sim 90 \mathrm{~km}$ at Disko Island to $\sim 65 \mathrm{~km}$ at Baffin Island, with similar thickness variations being

17 evident for magmatism in the Faroe Islands, Faroe-Shetland Basin and the British Palaeogene

18 Igneous Province (BPIP). Mean pressure of melting $\geq$ final pressure of melting and the two values converge for melting columns with a melting interval of $<1.5 \mathrm{GPa}$, regardless of $\mathrm{T}_{\mathrm{P}}$.

In particular, the majority of BPIP magmas were mostly generated in the garnet-spinel transition in the upper-mantle. Calculated and observed rare earth element distributions in NAIP lavas are entirely consistent with the melting regimes derived from major element melting models. This allows a calibration of rare earth element fractionation and melting conditions that can be applied to other flood basalt provinces. 


\section{INTRODUCTION}

28 The North Atlantic Igneous Province (NAIP; Fig. 1) is one of the best-known and most 29 comprehensively studied Large Igneous Provinces on Earth. Two major phases of volcanism 30 are recognised in the NAIP (Saunders et al,. 1997), the first beginning at 62 Ma and largely

31 restricted to western parts of the province (e.g. West Greenland, Baffin Island and the British

32 Palaeogene Igneous Province), and the second and larger phase beginning at $\sim 56$ Ma focused 33 more central to the site of NE Atlantic rifting (e.g. East Greenland and the Faroe Islands).

34 Most models for magmatism in the NAIP require a thermal anomaly to have been present 35 beneath the region from at least $61 \mathrm{Ma}$ until the present day, the anomaly being ancestral to 36 that responsible for present-day ridge-centred magmatism in Iceland. The evolution of the 37 NAIP was controlled by the complex tectono-magmatic processes associated with the 38 formation of rifted continental margins and the generation of new oceanic crust (Nielsen et 39 al., 2007; Hole et al., 2015). Most plate reconstructions place the centre of the thermal 40 anomaly beneath West Greenland at $\sim 65 \mathrm{Ma}$, with an eastward migration over the next $20 \mathrm{Ma}$ 41 (Lawver \& Müller, 1994; Milhaffy et al., 2008). Over the period 64-58 Ma magmatism was 42 widespread within the NAIP which has led to difficulties reconciling the distribution of 43 magmatism with a simple $2000 \mathrm{~km}$ diameter thermal anomaly (e.g. Mihalffy et al., 2008;

44 Shorttle et al., 2014; Hole et al., 2015). Indeed, some magmatism in the British Palaeogene 45 Igneous Province would have occurred at the very margins of the thermal anomaly and at the 46 same time, near-primary picritic magmas were being emplaced in West Greenland and on 47 Baffin Island.

48 Any study of magmatism associated with a thermal anomaly necessarily requires 49 knowledge of mantle potential temperature (ТP). ТP expresses the mantle temperature 50 projected along the solid-state adiabat to surface pressure. The $\mathrm{MgO}$ content of volatile51 deficient primary magma generated by melting mantle peridotite is positively correlated with 
52 the temperature of the mantle. Based on this fundamental observation, Herzberg \& Gazel 53 (2009) demonstrated that the thermal anomalies that are responsible for melt generation in 54 both ocean and continental large igneous provinces (LIPs) are of variable temperature and 55 undergo secular cooling. In particular, Herzberg \& Gazel (2009) proposed that the Icelandic 56 plume required a very high cooling rate, from $\mathrm{TP}=1550-1650^{\circ} \mathrm{C}$ to values as low as $1460^{\circ} \mathrm{C}$ 57 in a matter of $5 \mathrm{Ma}$. The record of magmatism for the Galápagos plume reveals two different 58 cooling rates (Trela et al. 2015). The first occurred between $\sim 90$ and $70 \mathrm{Ma}$ when $\mathrm{T}_{\mathrm{P}}$ 59 changed from $\sim 1650$ to $1550^{\circ} \mathrm{C}$ which was considered to represent the change from melting 60 at the plume-head to that at the plume tail (Trela et al. 2015). From $\sim 70$ Ma to present time, 61 the plume cooled from $\sim 1550$ to $1500^{\circ} \mathrm{C}$ (Trela et al., 2015). Consequently estimates for the 62 rate of secular change in $\mathrm{T}_{\mathrm{P}}$ associated with LIPs vary considerably.

63 Because magmatism in the NAIP was geographically widespread as well as having 64 longevity, the province potentially affords an opportunity to examine both spatial and 65 temporal variations in $T_{P}$ throughout the lifetime of a large igneous province. A number of existing studies have used a variety of different models to assess $T_{P}$ at specific locations in 67 the NAIP (e.g. Coogan et al., 2014; Larsen \& Pedersen, 2000; 2009; Scarrow \& Cox, 1995; 68 Scarrow et al., 2000; Hole et al., 2015; Hole, 2015; Kerr et al., 1999). Some $\mathrm{T}_{\mathrm{P}}$ 69 determinations have been made using olivine geothermometry (e.g. Larsen \& Pedersen, 2000; 70 2009; Hole et al., 2015), some using comparisons of major element data with experimental 71 studies (Scarrow \& Cox, 1995; Scarrow et al., 2000) and others have relied on determining 72 pressure of melting from the fractionation of rare earth elements (REE) and hence estimating $73 \mathrm{~T}_{\mathrm{P}}$ (e.g. Kerr et al., 1999). Most recently, the petrological model PRIMELT of Herzberg \& 74 Asimow (2008) has been used to estimate $T_{P}$ for picrites from Baffin Island in the extreme 75 west of the NAIP and for parts of the British Palaeocene Igneous Province (BPIP) in the 76 southeast of the NAIP (Hole, 2015; Hole et al., 2015; Millett et al,. 2015). 
77 Foulger (2012) highlighted the fact that methods for estimating mantle temperature suffer 78 from ambiguity of interpretation with composition and partial melt, controversy regarding 79 how they should be applied, lack of repeatability between studies using the same data, and 80 insufficient precision to detect the $200-300^{\circ} \mathrm{C}$ temperature variations postulated. Here we 81 present the results of a detailed study of the whole of the NAIP which includes the 82 determination of $\mathrm{T}_{\mathrm{P}}$ for 302 primitive basalts using the PRIMELT3 model of Herzberg \& 83 Asimow (2015). This single-model approach produces results that are internally consistent and can resolve $\mathrm{T}_{\mathrm{P}}$ to $\pm 42^{\circ} \mathrm{C}$. We show that the results obtained agree well with those derived from some other, but not all, studies and conclude that the integration of the results from major element modelling with trace element variations provides a tool of great utility for the understanding the petrogenesis of flood basalts. The purpose of this study is not to debate the existence of mantle plumes, but to provide a new, internally consistent, $\mathrm{T}_{\mathrm{P}}$ dataset for others to utilize in further debate.

\section{STRATIGRAPHY AND AGE OF NAIP MAGMATISM}

91 The relative and absolute ages of magmatism in the NAIP are based on an integration of 92 isotopic ages, magnetostratigraphy and biostratigraphy (Fig. 2). Significant debate, however, 93 still remains regarding the age of some parts of the NAIP due to conflicts between biostratigraphical and Ar-Ar / K-Ar isotopic age determinations for the commonly low K tholeiitic basaltic rocks of the main lava sequences (e.g. Passey \& Jolley 2009; Cramer et al. 2013). The oldest lavas in the province are those of the 62.5-61 Ma Vaigat Formation (Larsen 97 et al., 2015) of Baffin Island and West Greenland (mainly Disko Island; Fig.1). Magmatism 98 was continuous in West Greenland from 62-58Ma, followed by a magmatic hiatus at 56-58 99 Ma followed by continued magmatism from 56 until $53 \mathrm{Ma}$ (Larsen et al., 2015). The age of 100 British Palaeogene Igneous Province (BPIP; Fig. 1b) volcanic rocks is constrained by crosscutting relationships with dated intrusive rocks and interbedded acid lavas (Hamilton et al., 
102 1998; Chambers \& Pringle, 2001; Ganerød et al., 2010). The Tardree Rhyolite Complex in 103 Northern Ireland gives a U-Pb zircon age of $61.32 \pm 0.09 \mathrm{Ma}$ and sits between the Lower and 104 Upper Basalt Formations of the Antrim Lava Group. The Skye Main Lava Series (SMLS) is 105 younger than the Rum layered igneous complex $(60.53 \pm 0.08 \mathrm{Ma})$ but is intruded by the 106 Cuillin gabbro (zircon U-Pb age of $58.91 \pm 0.07 \mathrm{Ma}$ ). The Mull Plateau Lava Formation 107 (MPLF) is cut by the Loch Ba Ring Dyke (58.12 \pm 0.13 Ma; Chambers \& Pringle, 2001) a 108 best-estimate for extrusion of the MPLF being $\sim 60.5 \mathrm{Ma}$, although biostratigraphical 109 constraints suggest a rather younger age for the MPLF ( $\sim 55 \mathrm{Ma}$; Jolley \& Bell, 1997). The 110 Faroe Island Basalts Group (FIBG) spans the Palaeocene-Eocene Thermal Maximum 111 (PETM; 55.8 Ma), with the stratigraphically oldest Lopra and Beinisvørð formations being 112 pre-break-up and the stratigraphically younger Malinstindur and Enni formations being syn113 break-up, which are comparable with the ages determined for Geike Plateau and Milne Land 114 formations of East Greenland (Larsen et al., 1999; 2009; Peat et al., 2008; Passey \& Jolley, 115 2009). Overall, the NAIP lavas under consideration here span 5-8 Ma of stratigraphy. In 116 addition, at $\sim 60-61 \mathrm{Ma}$, lavas are distributed over a wide geographical area in relationship to 117 the position of the proposed plume centre.

\section{CALCULATION OF PRIMARY MAGMA COMPOSITIONS}

119 The model PRIMELT3 and the associated macro MEGAPRIMELT (Herzberg \& Asimow, 120 2015) both of which are derivatives of PRIMELT2 (Herzberg \& Asimow, 2008) and 121 PRIMELT (Herzberg \& O'Hara, 2002), has been used here to generate primary magma 122 compositions from major element data on lavas. Hereafter this will be referred to as simply 123 PRIMELT. PRIMELT software uses a mass balance solution to the primary magma problem 124 calibrated to fertile peridotite KR-4003, derived from a parameterization of experimentally 125 determined partial melt compositions (Herzberg \& O’Hara, 2002; Herzberg, 2004a; 2004b; 126 2006; Walter, 1998). PRIMELT uses both forward and inverse modelling to constrain a 
127 unique solution for primary magma composition. This is achieved by computing a melt

128 fraction that is common to both partial melts of mantle peridotite and to the primitive 129 magmas from which the lava in question was derived (Herzberg \& Asimow, 2008; 2015). In 130 this way, it differs from other methods that use olivine composition to constrain primary 131 magma composition (e.g. Lee et al. 2009; Putirka, 2008; Putirka et al., 2007; Courtier et al., 132 2007). Critical aspects of the PRIMELT model are that melts must have had olivine as the 133 sole liquidus phase during crystallization and melt must have been derived from volatile134 deficient peridotite. Melts which show evidence of early augite crystallization can be 135 effectively identified by the use of covariations between $\mathrm{MgO}$ and $\mathrm{CaO}$, because augite 136 causes significant fractionation of $\mathrm{CaO}$ relative to $\mathrm{MgO}$, but olivine does not, and the data set 137 used here has been filtered accordingly. In addition, $\mathrm{T}_{\mathrm{P}}$ information cannot be obtained for 138 melts derived from pyroxenite sources within the upper mantle, and such samples are 139 identified because of their deficiency in $\mathrm{CaO}$ for a given $\mathrm{MgO}$ content compared to melts 140 from mantle peridotite. PRIMELT contains an algorithm that identifies such samples 141 (Herzberg \& Asimow, 2015; 2008).

142 Construction of adiabatic $\mathbf{P}-\mathbf{T}$ pathways and estimates of $\mathbf{T}_{\mathbf{P}}$

143 For primitive basalts that have crystallized only olivine, reverse-modelling involving the 144 incremental addition or subtraction of equilibrium olivine to the measured bulk-rock 145 composition allows the generation of a suite of potential parental melt compositions 146 (Herzberg et al., 2007). A model parental magma is defined by the coincidence of an olivine 147 addition array with a 'target' olivine phenocryst composition having the maximum Fo content 148 (Herzberg \& Asimow, 2008). Comparison of parental melts compositions with primary melt 149 compositions determined from forward models of peridotite melting, allows $T_{P}$ that is 150 required to generate the melt to be estimated (Herzberg \& Asimow, 2008). The initial 151 pressure of intersection of the dry peridotite solidus $(P i)$ can be determined from $\mathrm{T}_{\mathrm{P}}$. Since 
152 the $\mathrm{MgO}$ content of an accumulated fractional melt does not change substantially as melt 153 fraction increases during decompression, the adiabatic temperature-pressure melting path is 154 nearly coincident with the olivine liquidus such that the P-T pathway of the primary melt to 155 the surface can be simulated. Fig. 3 is a schematic pressure-temperature diagram illustrating 156 the relationships between the principal parameters that are derived during the generation of a 157 modelled primary magma composition using PRIMELT. The example used is Vaigat 158 Formation olivine-phyric basalt BI/CS/8 from Baffin Island (Starkey et al. 2009) which has a 159 whole-rock content of $9.7 \mathrm{wt} \% \mathrm{MgO}$. PRIMELT calculates the primary magma to this basalt 160 to contain $19.0 \mathrm{wt} \% \mathrm{MgO},(27.6 \%$ olivine addition to the analysed composition) which 161 requires $\mathrm{T}_{\mathrm{P}}=1540^{\circ} \mathrm{C}$. The intersection of the dry peridotite solidus and the $1540^{\circ} \mathrm{C}$ adiabat 162 gives the initial pressure of melting $\mathrm{P} i=4.2 \mathrm{GPa}$ at $\mathrm{T} \sim 1620^{\circ} \mathrm{C}$ (Fig. 3).

163 Effects of variations in peridotite composition on $T_{P}$.

$164 \mathrm{The} \mathrm{MgO}$ and $\mathrm{FeO}$ contents of $\mathrm{KR}-4003$ are two of the fundamental values from which all 165 other PRIMELT parameters are derived. Decreasing the $\mathrm{FeO} / \mathrm{MgO}$ of the mantle peridotite 166 source composition, which can be achieved by melt extraction (depletion), will give higher $167 \mathrm{~T}_{\mathrm{P}}$ than that for models derived from KR-4003. To examine the magnitude of these effects, 168 we have calculated the compositions of residues after melt extraction from KR-4003 of 169 natural samples covering a range of $\mathrm{T}_{\mathrm{P}}=1360-1600^{\circ} \mathrm{C}$ and $F-A F M \sim 0$ to 0.3 , using equation 170 (9) of Herzberg \& Asimow (2015). Detailed descriptions of these estimates are given in 171 Electronic Appendix 1, which may be downloaded from the Journal of Petrology Web site at 172 http://www.petrology.oupjournals.org. Estimates were only made for $\mathrm{SiO}_{2}, \mathrm{FeO}, \mathrm{MgO}$ and $173 \mathrm{CaO}$ since $\mathrm{KR} 4003$ is somewhat deficient in $\mathrm{TiO}_{2}$ and $\mathrm{Na}_{2} \mathrm{O}$ and high in $\mathrm{K}_{2} \mathrm{O}$, and $\mathrm{P}_{2} \mathrm{O}_{5}$ 174 compared to typical peridotites of similar fertility (Herzberg \& Asimow, 2015). The MgO 175 and $\mathrm{FeO}$ content of the various residues derived has then been used as the $\mathrm{MgO}$ and $\mathrm{FeO}$ 176 content of the peridotite source for PRIMELT, and sample BI/CS/8 has then been re- 
177 modelled using the melt residue values as the peridotite source. An increase in $\mathrm{T}_{\mathrm{P}}$ of $\sim 100^{\circ} \mathrm{C}$

178 is achieved for a decrease in $\mathrm{FeO} / \mathrm{MgO}$ of the peridotite source from $\sim 0.211$ to $\sim 0.174$. This

179 is equivalent to the depletion achieved in the residue from fertile peridotite KR-4003 after

180 extraction of a melt similar in composition to that being produced today at Mauna Kea. Such

181 depletion is considered unlikely in nature, and in addition, the low $\mathrm{CaO}$ content of the residue

182 would render the peridotite of low fertility. An increase in $\mathrm{T}_{\mathrm{P}}$ of $\sim 50^{\circ} \mathrm{C}$ is achieved for

$183 \mathrm{FeO} / \mathrm{MgO}=0.19$ which is a similar to the composition of depleted abyssal peridotite RC27-

184 9-30 (Baker \& Beckett, 1999; Herzberg \& O’Hara, 2002). Detailed discussions on the choice

185 of the peridotite source for PRIMELT are given elsewhere (e.g. Herzberg \& O’Hara, 2002)

186 and here we wish to acknowledge the fact variability in the composition of mantle peridotite

187 can affect $T_{P}$ values and other petrological parameters used in this study.

188 Melt fraction, final pressure of melting and mean pressure of melting

189 Mantle peridotite partially melts at low melt fractions to produce melt droplets that are 190 efficiently removed from the residue by buoyancy-driven draining. During decompression 191 melting, the melt droplets mix to produce an "aggregate" or accumulated fractional melt $192(A F M)$. The melt fraction $(F-A F M)$ is uniquely defined by the $\mathrm{MgO}$ and $\mathrm{FeO}$ contents of any 193 accumulated fractional melt. It does not depend on the temperatures and pressures at which 194 melting begins and ends, and applies to all polybaric and isobaric accumulated fractional 195 melting paths (Herzberg \& O'Hara, 2002). However, in nature mantle peridotite melts 196 progressively during decompression along an adiabatic T-P path, generating accumulated 197 fractional melts with lower $\mathrm{FeO}$ at nearly constant $\mathrm{MgO}$. The final melting pressure (Pf), 198 which represents the pressure at which the last drop of melt was produced, can be estimated 199 from the melt fraction and $\mathrm{P} i$. The precise method for determining $\mathrm{P} f$ is dependent on both 200 the composition of the primary magma and the range of pressures under consideration. 201 Details of the calculation methods used here are given in Electronic Appendix 2. For sample 
$202 \mathrm{BI} / \mathrm{CS} / 8, \mathrm{P} f=1.9 \mathrm{GPa}$ (Fig. 4) which corresponds to $F-A F M \sim 0.3$ at a temperature of $2031520^{\circ} \mathrm{C}$ along the $19.0 \mathrm{wt} \% \mathrm{MgO}$ isopleth (Fig. 3). $\mathrm{P} f$ is also useful because it allows the 204 total depth of the melting column to be estimated and gives the approximate depth of 205 lithosphere-asthenosphere boundary (Gazel et al., 2011). However, complex phase 206 transitions at high pressures limit Pf estimates to $\leq 3.5 \mathrm{GPa}$ (Herzberg \& Gazel, 2009).

207 Lee et al. (2009) provided a magma thermo-barometer for calculating the average pressure 208 and temperature of melt segregation from the mantle for primary magma compositions (here 209 referred to as $\mathrm{Pm}$ ). Calculation of $\mathrm{P} m$ is based on the silica activity in olivine and 210 orthopyroxene saturated melts (Lee et al., 2009) and gives the mean pressure of melting over 211 the depth of a melting column with an uncertainty of $\pm 0.2 \mathrm{GPa}$. P $m$ is therefore is always $\geq$ $212 \mathrm{P} f$ and is comparable to the mean pressure of melting described by other workers (e.g. Klein 213 \& Langmuir, 1987; Albarède, 1992; Hole \& Saunders, 1996). Here, we have calculated Pm 214 from primary magma compositions derived from the PRIMELT model for which $\mathrm{P} f$ is 215 therefore also available. For sample BI/CS/8 (Fig, 3) the Lee et al. (2009) geo-barometer 216 indicates $\mathrm{P} m \sim 2.6 \mathrm{GPa}$ compared to $\mathrm{P} f=1.9 \mathrm{GPa}$. Continued rise of the parental magma to $217 \mathrm{BI} / \mathrm{CS} / 8$ to pressures lower than $1.9 \mathrm{GPa}$ occurred along the olivine liquidus and was 218 accompanied by $\sim 28 \%$ olivine crystallization but without further melting.

\section{Residual mantle mineralogy}

220 The three residual mantle mineralogies that are predicted by PRIMELT are garnet peridotite 221 or spinel peridotite or harzburgite. These residues are the solid that was left behind, not the 222 solid in equilibrium with the aggregate primary melt. The residue must therefore have a 223 mineralogy that reflects the final pressure of melting for the primary magma in question. 224 Lithology of the residue is predicted using a molecular projection of primary magma 225 compositions onto the plane Ol-An-Qz from or towards diopside which has three 226 compositional fields representing spinel peridotite, garnet peridotite and harzburgite residues 
227 (Fig. 4). For any primary magma, $\mathrm{P} f$ must be within the pressure-temperature range for the 228 stability of the aluminous phase (spinel or garnet) in the residue. The exhaustion of 229 clinopyroxene during melting of mantle peridotite is dependent on $F$ - $A F M$ ('cpx-out' line in 230 Fig. 3) and represents the transition from a spinel peridotite residue to a harzburgite residue. 231 Inspection of Figs 3 and 4 shows that for BI/CS/8 initial melting took place within the garnet 232 stability field of the upper-mantle, and then for $\mathrm{P} f=3.1-2.9 \mathrm{GPa}$ in the garnet-spinel 233 transition, and finally in the spinel stability field of the upper-mantle. Harzburgite was the 234 residual lithology for the final drop of melt at $\mathrm{P} f=1.9 \mathrm{GPa}$ (Fig. 4). However, the mean 235 pressure of melting for $\mathrm{BI} / \mathrm{CS} / 8(\mathrm{P} m=2.6 \mathrm{GPa})$ is within the spinel stability field of the 236 upper mantle.

\section{Melting of volatile-bearing peridotite}

238 Mantle peridtotite that contains $\mathrm{H}_{2} \mathrm{O}$ or $\mathrm{CO}_{2}$ or both, melts at lower temperatures than volatile 239 deficient ('dry') peridotite of the same silicate major element composition at the same 240 pressure (e.g. Dasgupta et al., 2007; Metrich et al., 2014). Melting in the presence of $\mathrm{CO}_{2}$ 241 drives primary magma compositions towards more silica under-saturated compositions with 242 higher $\mathrm{CaO}$ than for melting of dry peridotite (Dasgupta et al., 2007). PRIMELT utilizes this 243 information in an algorithm that satisfactorily identifies primary magmas derived from 244 peridotite with $>\sim 0.5 \mathrm{wt} \% \mathrm{CO}_{2}$ (Herzberg \& Asimow 2008) and such compositions have 245 been discounted in this study. For $\mathrm{H}_{2} \mathrm{O}$-bearing peridotite an appropriate algorithm cannot be 246 derived principally because of a lack of suitable data. However, Jamtveit et al. (2001) 247 reported water content of olivine from a number of volcanic rocks from the NAIP, including 248 Vaigat Formation picrites and basalts from the Faroe Islands, all of which had $\mathrm{H}_{2} \mathrm{O}$ contents 249 that were below detectable limits $(<0.5 \mathrm{wt} \%)$. East Greenland lavas with determinable levels 250 of $\mathrm{H}_{2} \mathrm{O}$ in olivine, indicative of $>300 \mathrm{ppm} \mathrm{H}_{2} \mathrm{O}$ in the mantle source (Jamtveit et al., 2001), 251 are mostly silica under-saturated compositions (alkali picrite and nephelenite) which do not 
252 yield PRIMELT solutions. Nichols et al. (2002) reported values of 620-920 ppm for the 253 mantle source of basalts beneath Iceland, but these estimates were dependent on the degree of 254 melting assumed (Nichols et al. 2002). However there are no full major element analyses for 255 these samples and so their significance cannot be assessed here. In a more general context, 256 Peslier and Bizmis (2015) showed that the bulk water content of Hawaiian peridotite 257 xenoliths is 50-100 ppm and Adria et al. (2012) concluded that hydrous partial melting 258 cannot occur at 4.5-7.5 $\mathrm{GPa}$ for $\mathrm{H}_{2} \mathrm{O}$ concentrations in the range 50-200 ppm, which are 259 typical of the convecting upper-mantle sampled by mid-ocean ridge basalts (MORB). While 260 we cannot totally discount a role for $\mathrm{H}_{2} \mathrm{O}$-bearing peridotite in the generation of NAIP 261 primary magmas based on the currently available data, for the remainder of this study, we 262 make the assumption that melting occurred under anhydrous conditions.

\section{Crustal contamination}

264 Because the rocks making up the continental crust in the area of the NAIP are of considerable 265 antiquity, they have characteristically unradiogenic $\mathrm{Nd}$ - and $\mathrm{Pb}$-isotopic compositions with 266 the most contaminated basalts having $\varepsilon \mathrm{Nd}_{\mathrm{T}}=-30$ and ${ }^{206} \mathrm{~Pb} /{ }^{204} \mathrm{~Pb}=14.3$ (Thompson et al., 267 1986; Dickin et al., 1987; Saunders et al., 1997; Fowler et al., 2003). Additionally, because 268 primitive magmas of the NAIP have low REE abundances, any interaction with crust readily 269 moves magma compositions to unradiogenic Nd-isotopic compositions (e.g. Skye Main Lava 270 Series and Mull Plateau Lava Formation $\varepsilon \mathrm{Nd}_{\mathrm{T}}$ as low as -30; Thompson et al., 1986; Dickin 271 et al., 1987; Thompson \& Morrison, 1988. Vaigat Formation $\varepsilon \mathrm{Nd}_{\mathrm{T}} \sim-21$ and ${ }^{206} \mathrm{~Pb} /{ }^{204} \mathrm{~Pb}$ 272 15.5; Larsen \& Pedersen 2009). For West Greenland lavas, the majority which have 273 unradiogenic $\mathrm{Nd}$-isotopic compositions $\left(\varepsilon \mathrm{Nd}_{\mathrm{T}}-20.0\right.$ to 0.0$)$ are quartz-normative basalts 274 which do not provide PRIMELT solutions; indeed no $Q z$-normative NAIP basalts provide 275 solutions for primary magmas by this method. For the NAIP data set used in this study, all 276 samples which yield primary magma solutions and for which Nd-isotopic compositions are 
277 available (44 in all) have $\varepsilon \mathrm{Nd}_{\mathrm{T}}>4.0$ and 38 samples have $\varepsilon \mathrm{Nd}_{\mathrm{T}}>6.0$. In addition, elevation of

278 key trace element ratios above values expected for the upper-mantle can also be used to 279 identify possible crustal interaction (e.g. La/Nb, Th/Nb, Ba/Zr; Thompson et al., 1982; Kent 280 \& Fitton, 2000; Hole et al., 2015). Where such data are available, we again find that all 281 samples which yield primary magma solutions carry no evidence of interaction with 282 continental crust. This is perhaps not surprising since addition of partial melts of fusible crust 283 to a mantle-derived mafic magma will cause phase changes which will mean that inverse 284 modelling to a parental and primary magmas is unlikely to succeed. Consequently, it seems 285 that the PRIMELT model satisfactorily identifies samples that have undergone significant 286 crustal interaction and does not provide a primary magma solution for them.

\section{RESULTS FOR THE NAIP}

\section{Data sources and model parameters}

289 Published data that were generated from previous versions of PRIMELT have been 290 recalculated to the new dry peridotite solidus parameters of Herzberg \& Asimow (2015). 291 Data were taken from the GEOROC database, with total iron recalculated to FeO where 292 necessary. Samples with $\geq 8.5 \mathrm{wt} \% \mathrm{MgO}$ were used to minimize complex fractionation 293 effects at lower contents of $\mathrm{MgO}$. The majority of samples used were olivine tholeiites which 294 exhibit early iron enrichment, and it has therefore been assumed that $\mathrm{Fe}_{2} \mathrm{O}_{3} / \mathrm{TiO}_{2}=0.5$. Whilst 295 some basalts from the Vaigat Formation are $N e$-normative alkali olivine basalts, $\mathrm{Fe}_{2} \mathrm{O}_{3} / \mathrm{TiO}_{2}$ 296 has also been set to 0.5 because $N e$ makes up $<5 \%$ of the norm. Results obtained from 297 PRIMELT are summarized in Table 1 and illustrated in Figs 5-8. For individual 298 stratigraphical units, or in some cases, geographical regions, mean values of $\mathrm{T}_{\mathrm{P}}, \mathrm{P} i, \mathrm{P} f$ and $F$ $299 A F M$ are given (Table 1$)$ and the uncertainty is quoted at 2 standard deviations $(2 \sigma)$ on the 300 mean of the population. The internal uncertainty in $T_{P}$ determination by PRIMELT is 301 approximately $\pm 30^{\circ} \mathrm{C}$ and that for $\mathrm{P} i, \mathrm{P} m$ and $\mathrm{P} f \pm 0.3 \mathrm{GPa}$ (Herzberg \& Asimow, 2008; Lee 
302 et al., 2009). Pm was calculated from the PRIMELT primary magma solutions using the 303 method of Lee et al. (2009). Results for geographical and stratigraphical subdivisions of the 304 NAIP will be considered in turn below. In all cases, PRIMELT3 results refer to the locus of 305 magma generation, which for some areas (e.g. BPIP) is not necessarily the locus of final 306 magma emplacement (Hole et al., 2015). The full dataset of PRIMELT3 solutions is given in 307 Electronic Appendix 4.

308 Vaigat and Maligat formations (West Greenland and Baffin Island).

309 Vaigat Formation lavas from Disko and Baffin islands provided 126 PRIMELT solutions 310 with $\mathrm{T}_{\mathrm{P}}$ varying from 1496 to $1639^{\circ} \mathrm{C}$. Seven samples from Disko Island yield $\mathrm{T}_{\mathrm{P}} 1606$ $3111639^{\circ} \mathrm{C}$ requiring initial intersection of the dry peridotite solidus at 5.9-7.1 GPa (Fig. 4). 312 These samples form a distinct group in Fig. 4 and have $\mathrm{FeO}$ contents $>0.5$ wt $\%$ higher than 313 all other Vaigat Formation basalts. The remaining 119 Vaigat Formation lavas have a normal 314 distribution of $\mathrm{T}_{\mathrm{P}}$ with $99.7 \%$ of samples falling within $2 \sigma\left(38^{\circ} \mathrm{C}\right)$ of the mean of $1541^{\circ} \mathrm{C}$ and 315 with a median value of $1544^{\circ} \mathrm{C}$. We consider $\mathrm{T}_{\mathrm{P}} \sim 1540^{\circ} \mathrm{C}$ to be the best estimate for Vaigat 316 Formation magmatism. Melting ceased at $<2.0 \mathrm{GPa}$ and melt fractions produced were in the 317 range $F=0.10$ to 0.32 , with the mean melt fraction being $0.26 \pm 0.06$. There is no evidence 318 of any stratigraphical variation in melting regime within the Vaigat Formation, and similarly 319 there are no differences in melting regimes for the N-type and E-type magmas described by 320 Dale et al. (2009) and Starkey et al. (2009). However, there are significant differences in the 321 melting regimes at Baffin Island compared to Disko Island. For Baffin Island lavas, the 322 residual lithology was spinel peridotite, or harzburgite with only four samples having garnet 323 peridotite as the residual lithology (Fig. 4). Pm beneath Baffin Island was $2.8 \pm 0.8 \mathrm{GPa}$ 324 which for $\mathrm{T}_{\mathrm{P}}=1530^{\circ} \mathrm{C}$ requires the majority of melt to have been formed in the spinel 325 stability field of the upper-mantle. By contrast, at Disko Island, garnet peridotite was the 326 residual lithology for 51 primary magmas, spinel peridotite for 25 primary magmas and 
327 harzburgite for only four primary magmas. $\mathrm{P} m(3.5 \pm 1.2 \mathrm{GPa})$ requires most melt to have

328 been formed in the garnet stability field of the upper-mantle beneath Disko Island.

329 Differences in $\mathrm{T}_{\mathrm{P}}$ and $\mathrm{P} i$ between the two locations are not large enough to explain the

330 differences in residual mineralogy between the two locations. Consequently $\mathrm{P} f$ and by

331 inference lithospheric thickness was the dominant control of extent of melting for the Vaigat

332 Formation. Two samples from the overlying Maligat Formation yielded PRIMELT solutions

333 with $\mathrm{T}_{\mathrm{P}}=1511$ and $1527^{\circ} \mathrm{C}$.

334 East Greenland

335 Results for East Greenland are little different from those reported by Herzberg \& Gazel 336 (2009). 19 samples provided solutions for melting of dry peridotite, 4 of which yielded $\mathrm{T}_{\mathrm{P}}$ $337=1640-1650,14$ yielded $\mathrm{T}_{\mathrm{P}}$ in the range $1508-1568^{\circ} \mathrm{C}$ and the remaining 5 samples yielded $\mathrm{T}_{\mathrm{P}}$ $338=1444-1468^{\circ} \mathrm{C}$. Eight samples from the Milne Land Formation (Fig. 1) have $\mathrm{T}_{\mathrm{P}}$ 1528$3391568^{\circ} \mathrm{C}$ which overlaps with the range of data for Vaigat Formation lavas. The lower 340 temperature group from East Greenland comprises basalts from the Hold With Hope 341 succession (Fig. 1) and two samples from the seaward-dipping reflector sequences sampled 342 during ODP Leg 152. Melt fractions produced were in the range $F=0.14$ to 0.28 . The mean 343 melt fraction was $0.27 \pm 0.08$ for the higher $T_{P}$ samples and $0.20 \pm 0.06$ for the lower $T_{P}$ 344 samples. The residual lithology for East Greenland primary magmas was spinel peridotite or 345 harzburgite

346 British Palaeogene Igneous Province (BPIP)

34749 samples from the BPIP yielded PRIMELT solutions, all of them from the regional dyke 348 swarm of the BPIP. Data have a normal distribution of $\mathrm{T}_{\mathrm{P}}$ with $99.7 \%$ of samples falling 349 within $2 \sigma\left(65^{\circ} \mathrm{C}\right)$ of the mean of $1504^{\circ} \mathrm{C}$ and with a median value of $1506^{\circ} \mathrm{C}$. $\mathrm{T}_{\mathrm{P}}$ variations 350 within the BPIP are therefore greater than the uncertainty of $\mathrm{T}_{\mathrm{P}}$ determinations by PRIMELT, 351 although we cannot distinguish any systematic stratigraphical or geographical variation in $T_{P}$. 
352 Extents of melting were variable $(F=0.04-0.27$; mean $=0.16 \pm 0.08)$ which is reflected in 353 the large range of $\mathrm{P} f(1.3-3.4 \mathrm{GPa})$. However, 43 out of 49 solutions gave $\mathrm{P} f>3.5-2.5 \mathrm{GPa}$. $354 \mathrm{P} m(2.9 \pm 0.8 \mathrm{GPa})$ is within error of $\mathrm{P} f$. 35 samples had a garnet peridotite residue, the 355 remainder a spinel peridotite residue. Melt inclusions in olivine phenocrysts from two MPLF 356 lava flows (Peate et al., 2012) have been treated in the same way as whole-rock data. Six 357 inclusions yielded PRIMELT solutions that suggest $\mathrm{T}_{\mathrm{P}}=1455-1482^{\circ} \mathrm{C}$ (Fig. 5). As an 358 independent assessment of the validity of using the PRIMELT model on melt inclusion data, 359 major element data for 23 melt inclusions from olivine phenocrysts in Vaigat Formation 360 picrites from Baffin Island (Yaxley et al., 2004) were processed, and these yielded $\mathrm{T}_{\mathrm{P}}=$ $3611533 \pm 22^{\circ} \mathrm{C}$ (Electronic Appendix 4) which is within the range for Vaigat Formation whole362 rock samples from the same location $\left(\mathrm{T}_{\mathrm{P}}=1532 \pm 48^{\circ} \mathrm{C}\right)$.

\section{Faroe Island Basalt Group (FIBG)}

36434 samples from the Enni and Malinstindur formations of the FIBG provided PRIMELT 365 solutions and data have a normal distribution of $\mathrm{T}_{\mathrm{P}}$ with $99.7 \%$ of samples falling within $2 \sigma$ $366\left(36^{\circ} \mathrm{C}\right)$ of the mean of $1519^{\circ} \mathrm{C}$ and with a median value of $1520^{\circ} \mathrm{C}$. No samples from the 367 Beinisvørð or Lopra formations, both of which stratigraphically underlie the Malinstindur 368 Formation (Fig. 2), yielded PRIMELT solutions. There are no distinctions between the 369 Malinstindur and Enni formations of the FIBG in terms of melting regime. Extents of melting 370 are greater for the FIBG $(F=0.22 \pm 0.06)$ compared to the BPIP $(F=0.16 \pm 0.04)$, a function 371 of melting to lower pressures in the FIBG $(\mathrm{P} f<2.4 \mathrm{GPa})$ rather than variation in $\mathrm{T}_{\mathrm{P}}$ and thus $372 \mathrm{P} i$. The residual lithology for FIBG primary magmas was spinel peridotite or harzburgite.

\section{Modern Iceland}

374 Icelandic lavas have been divided into two groups based on their geographical relationship to 375 the major rift-zones. Rift-zone magmatism is represented by lavas that were emplaced along 376 the continuation of the MAR on land, in the western (WVZ) and northern (NVZ) volcanic 
377 zones (Peate et al., 2010; Hardarson et al., 1997). Volcanism occurs on the rift-flanks at

378 Snaefell and Snæfellsnes. Snæfell represents the site of incipient rifting above the fringe of 379 the plume, and Snæfellsnes is situated on an old transform (Hards et al., 2000; Mattsson \& 380 Oskarsson, 2005). 41 rift-flank lavas gave $\mathrm{T}_{\mathrm{P}}=1455 \pm 28^{\circ} \mathrm{C}$ (Table 1; Fig. 8) whereas 56 lavas 381 from the rift-zones gave $\mathrm{T}_{\mathrm{P}}=1504 \pm 26^{\circ} \mathrm{C}$. The value of $\mathrm{T}_{\mathrm{P}} \sim 1450^{\circ} \mathrm{C}$ for the rift-flanks is in 382 agreement with the estimates given by Herzberg \& Gazel (2009), but the higher $\mathrm{T}_{\mathrm{P}}$ of $383 \sim 1500^{\circ} \mathrm{C}$ for the rift-zones is previously unreported. This establishes that there is a $\mathrm{T}_{\mathrm{P}}$ 384 gradient across modern Iceland which occurs on a scale of hundreds of km. For both rift385 zone and rift-flank magmatism there are large variations in $\mathrm{P} f(1.4-3.0 \mathrm{GPa})$. However, 386 because of $\mathrm{T}_{\mathrm{P}}$ variations, extents of melting are larger in the rift-zones $(F=0.17-0.30)$ than 387 on the rift-flanks ( $F=0.13-0.21)$ which is a consequence of the higher $\mathrm{P} i$ for the rift-zones $388(3.2-4.1 \mathrm{GPa})$ than the rift flanks $(2.7-3.2 \mathrm{GPa})$. There is no discernible difference in the 389 mean pressure of melting for the rift zones $(2.6 \pm 0.6 \mathrm{GPa})$ and for the rift-flanks $(2.3 \pm 0.6$ $390 \mathrm{GPa})$.

\section{DISCUSSION}

\section{Mantle potential temperature variations in the NAIP}

393 Ambient mantle $T_{P}$ is considered here to be that which is required to generate ocean ridge 394 basalts, which is $\sim 1350^{\circ} \mathrm{C}$ (Herzberg et al., 2007; Herzberg \& Gazel, 2009; Hole, 2015; Lee 395 et al. 2009). Whilst there is limited evidence to suggest $\mathrm{T}_{\mathrm{P}}>1600^{\circ} \mathrm{C}$ for some Disko Island 396 lavas, the majority of $>55$ Ma NAIP magmatism appears to have driven by a thermal 397 anomaly of ambient mantle $\mathrm{T}_{\mathrm{P}}+200^{\circ} \mathrm{C}$ that is $\sim 1550^{\circ}$. This is similar to $\mathrm{T}_{\mathrm{P}}$ for Hawaii at 398 present-day $\left(T_{P}=1540 \pm 20^{\circ} \mathrm{C}\right)$, slightly higher than that required for the generation of 399 basalts from the Ontong Java Plateau $\left(\mathrm{T}_{\mathrm{P}}=1524 \pm 5^{\circ} \mathrm{C}\right)$ and the Etendeka Province of 400 southwestern Africa $\left(T_{P}=1515 \pm 16^{\circ} \mathrm{C}\right)$ and considerably higher than that for many ocean 401 island basalts (Herzberg \& Asimow, 2008; Herzberg \& Gazel, 2009; Gazel et al., 2011; Hole, 
402 2015). In general, there are three distinct distributions of $T_{P}$ in the NAIP (Figs 6 and 7).

403 Firstly, Vaigat Formation and Milne Land Formation lavas required $T_{P} \sim 1550^{\circ} \mathrm{C}$. Secondly, 404 BPIP, FIBG and Iceland rift zone lavas all have very similar distributions of $\mathrm{T}_{\mathrm{P}}(1500$ $4051510^{\circ} \mathrm{C}$ ) which is $\sim 40-50^{\circ} \mathrm{C}$ lower than for Vaigat Formation lavas. Finally, Iceland rift-flank 406 lavas required $\mathrm{T}_{\mathrm{P}} \sim 1450^{\circ} \mathrm{C}$. As a statistical exercise, the combined $\mathrm{T}_{\mathrm{P}}$ values for Iceland Rift 407 Zones, the BPIP and FIBG give $\mathrm{T}_{\mathrm{P}}=1509 \pm 48^{\circ} \mathrm{C}$ and for the Vaigat Formation and Milne 408 Land Formation combined $\mathrm{T}_{\mathrm{P}}=1541 \pm 38^{\circ} \mathrm{C}$. A student's $t$-test $(t=4.31)$ shows that the 409 difference in these mean values is significant at the $99 \%$ confidence level. Consequently, we 410 identify three $T_{P}$ regimes during magmatism in the NAIP over the period 62-0 Ma, 411 corresponding to $\mathrm{T}_{\mathrm{P}}=1550^{\circ} \mathrm{C}, 1500^{\circ} \mathrm{C}$ and $1450^{\circ} \mathrm{C}$.

\section{Modern Iceland}

413 Herzberg \& Gazel (2009) argued that the Iceland plume underwent significant secular 414 cooling from the Palaeocene $\left(\mathrm{T}_{\mathrm{P}} \sim 1550^{\circ} \mathrm{C}\right)$ to the present $\left(\mathrm{T}_{\mathrm{P}} \sim 1450^{\circ} \mathrm{C}\right)$ whereas Herzberg \& 415 Asimow (2015) derived $\mathrm{T}_{\mathrm{P}}=1500^{\circ} \mathrm{C}$ from samples from the Western Rift-zone. The latter $\mathrm{T}_{\mathrm{P}}$ 416 is in good agreement with the rift-zone results presented here, and we therefore suggest that 417 secular cooling for the Iceland plume has been around $50^{\circ} \mathrm{C}$ in $55 \mathrm{Ma}$. Evidence suggests that 418 since $55 \mathrm{Ma}$, the Iceland plume has produced pulses of hotter than average material $(+25-$ $41930^{\circ} \mathrm{C}$ ) that expanded radially at up to $40 \mathrm{cmyr}^{-1}$, with periods of low magma productivity 420 represented by troughs between V-shaped ridges on the Reykjanes spreading Ridge (Parnell421 Turner et al., 2013; 2014; Poore et al., 2009; Hardarson et al., 1997). The possibility 422 therefore remains that the rift-zone $\mathrm{T}_{\mathrm{P}}$ of $\sim 1500^{\circ} \mathrm{C}$ represents the beginning of one such pulse, 423 and that the rift-flank $\mathrm{T}_{\mathrm{P}}$ of $1450^{\circ} \mathrm{C}$ represents the 'background' plume temperature. There is 424 also an additional possible role for $\mathrm{H}_{2} \mathrm{O}$ in the source-region of Icelandic basalts that cannot 425 be dismissed (Nichols et al. 2002). However, the key point is that for modern Iceland the 
426 assumption of a steady-state $\mathrm{T}_{\mathrm{P}} \sim 1450^{\circ} \mathrm{C}$ is not valid. Therefore $\mathrm{T}_{\mathrm{P}}$ fluctuations of at least

$427 \pm 50^{\circ} \mathrm{C}$ in the magmatic record of the NAIP might be expected.

428 Palaeocene-Eocene lavas

429 Within the older ( $>50 \mathrm{Ma})$ sequences of the NAIP there are some clear indicators of 430 variations in $T_{P}$ in time and space (Fig. 6). Magmatism was initiated in West Greenland and 431 on Baffin Island, on either side of the Davis Strait at $\sim 61 \mathrm{Ma}$ (Fig. 1). Whilst there is 432 evidence to suggest $\mathrm{T}_{\mathrm{P}}$ up to $1640^{\circ} \mathrm{C}$ at this time, $90 \%$ of $\mathrm{T}_{\mathrm{P}}$ determinations (a total of 119) 433 are in the range $1496-1600^{\circ} \mathrm{C}$ with a mean value of $\mathrm{T}_{\mathrm{P}}=1541 \pm 38^{\circ} \mathrm{C}$. Two samples from the 434 SDRS on the East Greenland margin, which are considered to be near age-equivalents of the 435 Vaigat Formation lavas (Larsen et al., 2015), give $\mathrm{T}_{\mathrm{P}}=1453$ and $1461^{\circ} \mathrm{C}$, suggesting a 436 change in $\mathrm{T}_{\mathrm{P}}$ of $\sim 100^{\circ} \mathrm{C}$ from West to East at $\sim 60-61 \mathrm{Ma}$. Basalts from the $\sim 55 \mathrm{Ma}$ Milne 437 Land Formation at Blosseville Kyst (Larsen et al., 2014; Waight et al., 2012) farther north 438 along the East Greenland margin (Fig. 1), give $\mathrm{T}_{\mathrm{P}} \sim 1540^{\circ} \mathrm{C}$. It is generally accepted that by $43955 \mathrm{Ma}$ the location of the plume centre had migrated to the east, to a position under central 440 Greenland. The $T_{P}$ values obtained from the Milne Land Formation basalts are consistent 441 with this hypothesis. Five samples from Upper Plateau Lava Series basalts from Hold With 442 Hope (Fig. 1) give $\mathrm{T}_{\mathrm{P}}=1485-1561^{\circ} \mathrm{C}$, and whereas these values are more variable, they are 443 not inconsistent with the relocation of the plume centre at that time.

444 FIBG lavas from the Malinstindur and Enni formations record $\mathrm{T}_{\mathrm{P}} \sim 1519 \pm 36^{\circ} \mathrm{C}$ (Fig. 6) $44530^{\circ} \mathrm{C}$ lower than for Vaigat Formation lavas. The Malinstindur and Enni Formations were 446 both emplaced during the syn-rift phase of Larsen et al. (1999), and are thought to have been 447 located $100-200 \mathrm{~km}$ to the south of the Central East Greenland succession at that time. The 448 pre-break-up lavas of the Faroe Islands (Lopra and Beinisvørð formations; Passey \& Jolley, 449 2009), which represent over $4 \mathrm{~km}$ of stratigraphy, underwent augite \pm plagioclase 450 fractionation and available samples do not yield PRIMELT solutions. However, the lower- 
451 most lavas from well 217/15-1 in the Faroe-Shetland basin are likely to be correlatives of the 452 Beinisvørð Formation of the FIBG (Millett et al. 2015) and these yielded $\mathrm{T}_{\mathrm{P}} \sim 1530^{\circ} \mathrm{C}$. 453 However, there are insufficient data to allow resolution of stratigraphical $\mathrm{T}_{\mathrm{P}}$ variations within 454 the FIBG, because $T_{P}$ variations are close to the uncertainty in $T_{P}$ determinations using PRIMELT.

$456 \mathrm{~T}_{\mathrm{P}}$ data obtained from BPIP whole-rocks $\left(\mathrm{T}_{\mathrm{P}}=1504 \pm 64^{\circ} \mathrm{C}\right)$ is restricted to samples from 457 the Preshal More and Central Mull formations which mostly occur in the regional dyke 458 swarm of the BPIP (Hole et al., 2015). These results suggest that BPIP magmatism took place 459 at $\mathrm{T}_{\mathrm{P}} \leq 1510^{\circ} \mathrm{C}$, whereas melt inclusion data suggest that the plateau-forming lavas resulted 460 from melting at $\mathrm{T}_{\mathrm{P}} \sim 1480^{\circ} \mathrm{C}$, which is consistent with estimates of Scarrow \& $\mathrm{Cox}$ (1995). If 461 the majority of the BPIP required $\mathrm{T}_{\mathrm{P}}<1510^{\circ} \mathrm{C}$, this value is lower than that for both the 462 younger (FIBG and East Greenland) and older (West Greenland) sequences to the north. The 463 exception is for the few slightly older Leg 152 SDRS samples which give cooler 464 temperatures. There is little doubt that the BPIP was on the periphery of the plume system at $465 \sim 60-61$ Ma (Fig. 1; Mihalffy et al., 2007; Hole et al., 2015) and it seems reasonable to 466 suggest that the distance of the BPIP from the plume head resulted in a smaller $\mathrm{T}_{\mathrm{P}}$ anomaly 467 than above the plume head itself. Certainly, the fact that the rare earth element distributions 468 in many BPIP plateau lavas had residual garnet in their mantle source requires a minimum $T_{P}$ 469 of $\sim 1475^{\circ} \mathrm{C}$ (Thompson et al., 1986; Kerr et al., 1999; Hole et al., 2015). However, it is also 470 apparent that a linear decrease in temperature with distance from the proposed plume head 471 during the Palaeogene is not supported by all the data. We conclude that at present, there is 472 no evidence to suggest that $\mathrm{T}_{\mathrm{P}}$ was $>1510^{\circ} \mathrm{C}$ beneath the $\mathrm{BPIP}$ at $\leq 61 \mathrm{Ma}$.

\section{Comparisons with other temperature estimates for the NAIP}

474 Larsen \& Pedersen (2000) calculated primitive melt compositions for magnesian lavas from 475 Disko Island by stepwise addition of equilibrium olivine to the composition of the glassy 
476 matrix of pillow lavas. Calculated primitive magmas had 20-21wt $\% \mathrm{MgO}$ and liquidus

477 temperatures of $1515-1560^{\circ} \mathrm{C}$ at $1.4-1.6 \mathrm{GPa}$. Temperatures and pressures of primary magma 478 segregation were $1563-1606^{\circ} \mathrm{C}$ and $2.8-3.6 \mathrm{GPa}$ respectively. Recalculating segregation 479 temperatures to $\mathrm{T}_{\mathrm{P}}$ gives $1538-1559^{\circ} \mathrm{C}$, values which are in excellent agreement with $\mathrm{T}_{\mathrm{P}}$ from 480 PRIMELT. Other $\mathrm{T}_{\mathrm{P}}$ estimates for the NAIP as a whole, based on a wide range of different 481 methods and assumptions (e.g. Gill et al., 1992; Scarrow et al., 2000), give $\mathrm{T}_{\mathrm{P}}=1420$ $4821600^{\circ} \mathrm{C}$ depending on the model applied. Maclennan et al. $(2001)$ derived $\mathrm{T}_{\mathrm{P}}=1480-1520^{\circ} \mathrm{C}$ 483 for modern Iceland based on REE inversion modelling and crustal accretion rates at 484 Herdubreid in the NVZ of Iceland. Herdubreid samples HBT1 to HBT5 (Appendix 3) yield 485 PRIMELT solutions with $\mathrm{T}_{\mathrm{P}}=1487-1498^{\circ} \mathrm{C}$. Parnell-Turner et al. (2014) used an average 486 excess Iceland plume temperature of ambient $\mathrm{T}_{\mathrm{P}}=150 \pm 50^{\circ} \mathrm{C}$ in a study of transient mantle 487 plume activity beneath Iceland from $55 \mathrm{Ma}$ to present-day, a range which is greater than that 488 given by PRIMELT solutions. However Howell et al. (2014) showed that for ambient $489 \mathrm{~T}_{\mathrm{P}}=1338^{\circ} \mathrm{C}$, and an Iceland plume with $\mathrm{T}_{\mathrm{P}}=1488^{\circ} \mathrm{C}\left(\right.$ ambient $\left.+150{ }^{\circ} \mathrm{C}\right)$, a thermal anomaly 490 of $\geq 55^{\circ} \mathrm{C}\left(1393{ }^{\circ} \mathrm{C}\right)$ would extend to $1000 \mathrm{~km}$ from the plume-head position. If the plume 491 was hotter during the Palaeocene with $\mathrm{T}_{\mathrm{P}}=1540^{\circ} \mathrm{C}$, as indicated by Vaigat Formation lavas, 492 then it may have been possible to produce absolute $\mathrm{T}_{\mathrm{P}} \geq 1500^{\circ} \mathrm{C} 1000 \mathrm{~km}$ from the plume 493 centre, assuming the plume position of Mihalffy et al. (2007). This would have been 494 sufficient to support the generation all NAIP magmas to the east of West Greenland, 495 particularly if the plume-head migrated eastwards through time.

496 Pressure of melting and lithospheric structure.

$497 \quad \mathrm{P} f$ is influenced by the thickness of the lithosphere above the site of melting and may be 498 used as a proxy for the depth to the lithosphere-asthenosphere boundary (LAB; Gazel et al., 499 2011). $\mathrm{P} m$ is based on the silica activity in olivine and orthopyroxene saturated melts and 500 reflects the mean extent of melting over the depth of the melting column (Klein \& Langmuir, 
501 1987; Albaréde, 1991; Hole \& Saunders, 1996; Lee et al., 2009). Whilst Pf must be within 502 the pressure-temperature range for the stability of the aluminous phase (spinel or garnet) in 503 the residue, $\mathrm{P} m$ is frequently higher than that indicated by the residual mineralogy from 504 melting. Thus for Vaigat Formation lavas from Baffin Island, Pf indicates pressures lower 505 than the garnet-spinel transition in the upper mantle, but P $m$ straddles the transition (Fig. 8). 506 A similar distribution of $\mathrm{P} f$ and $\mathrm{P} m$ is also exhibited by FIBG and Iceland rift-zone lavas. 507 Using a combination of $\mathrm{P} i, \mathrm{P} m$ and $\mathrm{P} f$, the average dimensions of melting columns for any 508 location at any $\mathrm{T}_{\mathrm{P}}$ can be estimated (Fig. 9). Values of $\mathrm{P} f$ represented in Fig. 9 are the mean $509 \mathrm{P} f$ of primary magmas with the lowest pressure residual lithology i.e. spinel peridotite or 510 harzburgite or both of these, for the locations in question. It is assumed that melting 511 columns are cylindrical which is a simplification because plumes are likely to deform as they 512 impact the base of the lithosphere (e.g. Saunders et al., 1997; Herzberg \& Asimow, 2015).

513 For Siqueiros MORB, $\mathrm{P} f \approx \mathrm{P} m \approx 1.4 \mathrm{GPa}$ (Fig. 9) indicating a depth of $50 \mathrm{~km}$ to the base 514 of the LAB, equivalent to 25 Myr old lithosphere (Lee, 2005). For the Ontong-Java Plateau, $515 \mathrm{P} f \approx 1.7 \mathrm{GPa}$ indicating a depth of $55 \mathrm{~km}$ to the LAB with a mean pressure of melting of $\sim 2.5$ 516 GPa. Ontong-Java Plateau lavas were therefore mostly generated in the spinel stability field 517 of the upper-mantle, with extensive melting $(F \sim 0.3)$ leaving a harzburgite reside. For 518 Icelandic rift-zones, magmas leaving a harzburgite residue, which are commonest at 519 Theistareykir, require $\mathrm{P} f \sim 1.5 \mathrm{GPa}$ with the LAB at $\sim 50 \mathrm{~km}$. Icelandic rift-flank magmas 520 have more consistent and higher $\mathrm{P} f \sim 2.1 \mathrm{GPa}(\sim 65 \mathrm{~km})$ compared to the rift-zone primary 521 magmas, but have a lower $\mathrm{T}_{\mathrm{P}}$ and $\mathrm{P} i$, and hence represent smaller melt fractions than rift-zone 522 primary magmas. The lithosphere thicknesses for Iceland derived here are therefore similar 523 to other estimates (e.g. the summary given by Barnhoorn et al., 2011).

524 At Baffin Island, the LAB was at $\sim 65 \mathrm{~km}$ depth and $\mathrm{P} m(\sim 2.8 \mathrm{GPa})$ was within the 525 spinel stability field of the upper mantle. The melting column for Disko Island was truncated 
526 at $\sim 2.8 \mathrm{GPa}$ representing a cap of $\sim 90 \mathrm{~km}$ of overlying lithosphere. $\mathrm{P} m \sim 3.3 \mathrm{GPa}$ requires

527 melting beneath Disko Island to have occurred in the presence of garnet, which is consistent 528 with the residual lithologies derived from PRIMELT. These observations are in good 529 agreement with those of Larsen \& Pedersen (2009) who argued for lithosphere $100 \mathrm{~km}$ 530 thick at Disko Island. This also implies that the LAB was at least $30 \mathrm{~km}$ thinner beneath 531 Baffin Island than Disko Island at $61 \mathrm{Ma}$. Palaeocene oceanic crust within palaeomagnetic 532 chron 27r, which ends at 62.0 Ma (Larsen et al., 2009) is present in the Davis Strait (Fig. 1). 533 The oldest Palaeocene volcanic rocks dated from the region are tholeiitic basalts dredged 534 from the Davis Strait High with an ${ }^{40} \mathrm{Ar} /{ }^{39} \mathrm{Ar}$ age of $63.0 \pm 0.7 \mathrm{Ma}$ (Larsen et al., 2009). The 535 geochemistry of these basalts indicates formation beneath a strongly attenuated continental 536 lithospheric lid (Larsen et al., 2009). Therefore, it is proposed that before the onset of 537 magmatism on Baffin Island, the lithosphere was already significantly thinned, allowing for 538 extensive decompression melting. Farther to the NE at Disko Island, it can be assumed that 539 the continental crust was still at its pre-stretching thickness resulting in a TBL thickness $540>100 \mathrm{~km}$.

541 The melting column for FIBG primary magmas is similar in its dimensions to that for 542 Baffin Island, but $\mathrm{T}_{\mathrm{P}}\left(\sim 1520^{\circ} \mathrm{C}\right)$ and $\mathrm{P} i(\sim 3.9 \mathrm{GPa})$ are a little lower than those for Baffin 543 Island. The mean $\mathrm{P} f$ values for the FIBG $(\sim 2.1 \mathrm{GPa})$ requires the LAB to have been at a 544 depth of $\sim 65 \mathrm{~km}$ at the time of generation of the Enni and Malinstindur formations lavas. 545 Farther to the south, in the Faroe-Shetland Basin (Fig. 1), basalts from the base of the lava 546 pile in well $217 / 15-1$ have $\mathrm{P} f \sim 3.0\left(\mathrm{~T}_{\mathrm{P}} \sim 1530^{\circ} \mathrm{C}\right)$, which requires the base of the lithopshere 547 to be $\sim 30 \mathrm{~km}$ deeper than beneath the Faroe Islands. The age of the lavas in $214 / 15-1$ is not 548 well constrained and consequently their relationship with break-up is not well-understood. 549 However the 217/15-1 lavas are likely to be equivalent to the Beinisvørð Formation of the 550 FIBG (Millett et al. 2015) and therefore may pre-date break-up. Whatever the age of the 
551 217/15-1 lavas, they provide evidence for significant fluctuations in the thickness of the 552 lithosphere in the Faroe Islands and Faroe-Shetland Basin area during NAIP magmatism, and 553 suggest that the lithosphere was thinned before magmas forming the Malinstindur and Enni 554 formations were generated.

555 Beneath the BPIP, the depth to the LAB was similar to that for Disko Island $(\sim 2.7 \mathrm{GPa}$ or $556 \sim 90 \mathrm{~km})$. However, since the samples which yield PRIMELT solutions are from the regional 557 dyke swarm of the BPIP, it is likely that they were emplaced at some distance from the site of 558 melting (Hole et al., 2015). Nevertheless, this depth estimate is consistent with previous 559 estimates based on distributions of the REE (Thompson, 1982; Kerr et al., 1999; Hole et al., 560 2015). An important feature of the BPIP melting column is that the combination of thick 561 lithosphere $(\mathrm{P} f \sim 2.7 \mathrm{GPa})$ and $\mathrm{T}_{\mathrm{P}} \sim 1500^{\circ} \mathrm{C}$ only allows limited extents of melting and $\mathrm{P} m(\sim$ $5622.9 \mathrm{GPa})$ approaches $\mathrm{P} f$. In addition, $\mathrm{P} m=2.9 \mathrm{GPa}$ requires most magma to have been 563 generated in the garnet-spinel transition of the upper mantle. This combination of $\mathrm{P} i, \mathrm{P} m$ and $564 \mathrm{P} f$ can only occur for $\mathrm{T}_{\mathrm{P}} \sim 1500^{\circ} \mathrm{C}$ and $\mathrm{P} f \sim 2.7 \mathrm{GPa}$ probably requiring a continental setting 565 to achieve. A small increase in $\mathrm{T}_{\mathrm{P}}$ or decrease in $\mathrm{P} f$ or both, would move $\mathrm{P} m$ into the spinel 566 stability field of the upper mantle as is does for the FIBG. The significance of this will be 567 discussed in the section on REE fractionation below.

568 Integration of rare earth element data and PRIMELT results.

569 Many existing studies of the petrogenesis of the igneous rocks of the NAIP have relied on 570 the use of trace elements, and in particular REE profiles, to constrain depths, pressures and 571 therefore, by inference, $\mathrm{T}_{\mathrm{P}}$ (e.g. Kerr et al., 1999; Tegner et al., 1998; Thompson et al., 1986; 572 1982; Hole et al., 2015). Here, we use the reverse process and examine the trace element 573 characteristics of lavas for which the PRIMELT model provides the conditions of melting. 574 REE data, where they are available, have been fractionation-correct for the amount of olivine 575 accumulation or removal given by the PRIMELT model using the partition coefficients given 
576 in Hole et al. (2015). Chondrite-normalized rare earth element (REE) profiles are shown in 577 Fig. 10 for selected samples which are light-REE depleted with chondrite normalized La/Sm $578<0.1\left([\mathrm{La} / \mathrm{Sm}]_{\mathrm{N}}\right)$. These samples also have $\Delta \mathrm{Nb}<0.0$ (Fitton et al., 1997) and as such can be 579 considered to have been derived by melting of mantle peridotite similar in composition to that 580 which produces modern MAR MORB distant from the Iceland plume system (Fitton et al. 581 1997; Hole et al. 2015). Consequently, we have assumed that the selected samples only 582 differ from one another in the detail of their respective melting regimes. In Fig. 10a-c, 583 samples have been grouped by the lithology of the melting residue as determined from the 584 PRIMELT model. Samples with garnet peridotite residual lithologies exhibit a characteristic 585 convex-upwards shape with $[\mathrm{La} / \mathrm{Sm}]_{\mathrm{N}}<1.0$ and $[\mathrm{Tb} / \mathrm{Yb}]_{\mathrm{N}}>1.0$, and all have $\mathrm{P} m>2.9 \mathrm{GPa}$, 586 a pressure which falls within the range for the spinel-garnet transition of the upper-mantle. 587 The majority of magmas with $\mathrm{P} m<2.8$ with a harzburgite residue have the same REE 588 profiles as primary magmas with a spinel peridotite reside. A small number of samples with 589 a spinel peridotite residue exhibit convex-upwards REE profiles (Fig. 10b) suggesting that 590 the majority of melting to produce these compositions must have taken place in the garnet591 spinel transition of the upper mantle, even though the $\mathrm{P} f$ may be in the spinel stability field of 592 the upper-mantle.

593 Relationships between $[\mathrm{La} / \mathrm{Yb}]_{\mathrm{N}}$ and $[\mathrm{Tb} / \mathrm{Yb}]_{\mathrm{N}}$ have been used by a number of authors 594 (e.g. Hunt et al. 2012; Hole et al. 2015) to determine 'deep' versus 'shallow' melting of 595 peridotite with deeper melting giving progressively higher $[\mathrm{Tb} / \mathrm{Yb}]_{\mathrm{N}}($ Fig. 11). The results of 596 the PRIMELT models and observed REE distributions are in general agreement in this 597 respect. Data points for Disko Island samples fall close to a model garnet peridotite melting 598 trajectory and data for Baffin Island basalts plots close to a spinel peridotite melting 599 trajectory (Fig. 11a). However, it is important to note that the precise position of melting 600 trajectories in Fig. 11 is model-dependent. Fig. 11b shows samples for which PRIMELT 
601 solutions are available. Samples with a garnet peridotite residue plot in the expected position 602 above the spinel melting trajectory. Samples with a harzburgite residue mainly plot along the 603 spinel melting trajectory, again an expected result. However, samples with a spinel peridotite 604 residue show considerable scatter in Fig. 11b. This is because PRIMELT results give the 605 residue at the final (lowest) pressure of melting. Consequently, primary magmas with $\mathrm{P} f \sim$ 2.7 may have a spinel peridotite residue, but will exhibit a garnet peridotite REE signature because the majority of melting took place in the garnet stability field of the upper-mantle. 608 This is consistent with $\mathrm{P} m$ values determined for such samples. We make the observation 609 here that the convex upward REE profiles are only likely to be generated under the specific 610 conditions where $\mathrm{P} m$ is within the garnet-spinel stability field of the upper-mantle. As we 611 noted above, in the NAIP, this requires the $\mathrm{LAB}$ to be at $\sim 95 \mathrm{~km}$ and $\mathrm{T}_{\mathrm{P}} \sim 1500^{\circ} \mathrm{C}$ which are 612 the prevalent conditions within the BPIP. In Fig. 10d REE patterns are shown for BPIP 613 basalts for which no PRIMELT solution is available, all of which exhibit convex upward 614 REE profiles. For the BPIP as a whole, covariations between $[\mathrm{La} / \mathrm{Yb}]_{\mathrm{N}}$ and $[\mathrm{Tb} / \mathrm{Yb}]_{\mathrm{N}}($ Fig. 615 11c) are consistent with melting in the garnet-spinel transition of the upper-mantle, with only 616 a small number of basalts having a spinel-only signature. Therefore REE distributions are 617 consistent with $\mathrm{T}_{\mathrm{P}}=1480-1510^{\circ} \mathrm{C}$ and a depth to the $\mathrm{LAB}$ of $\sim 90 \mathrm{~km}$.

\section{CONCLUSIONS}

619 Within the NAIP, we have identified sufficient PRIMELT primary magma solutions from a 620 number of locations to provide a framework for $T_{P}$ variations over a broad geographical area 621 from 61-0 Ma. However, lavas that occupy large sections of the stratigraphy of, for example 622 the BPIP (up to $2 \mathrm{~km}$ ) and the Beinisvørð Formation and Lopra Formation of the FIBG (> 4 $623 \mathrm{~km})$ do not yield any $T_{P}$ results. This is because of their evolved nature and their 624 crystallization of an assemblage of olivine + plagioclase \pm augite. This leads to relatively 625 large intervals of the NAIP stratigraphy for which methods such as PRIMELT cannot resolve 
$626 \mathrm{~T}_{\mathrm{P}}$ information. Integration and calibration of alternative approaches such as using REEs to 627 infer relative changes in melting depth (e.g. Tegner et al., 1998) with the PRIMELT method 628 may enable better insight into the time-dependent changes of $\mathrm{T}_{\mathrm{P}}$ in the future.

629 NAIP magmatism can be attributed to a thermal anomaly of ambient $\mathrm{T}_{\mathrm{P}}\left(1350^{\circ} \mathrm{C}\right)+200^{\circ} \mathrm{C}$.

630 We can find no evidence of secular cooling of more than $\sim 50^{\circ} \mathrm{C}$ in $61 \mathrm{Ma}$. The highest $\mathrm{T}_{\mathrm{P}}$ of $631 \sim 1550^{\circ} \mathrm{C}$ is recorded in the Vaigat Formation of West Greenland at $\sim 61 \mathrm{Ma}$ although there 632 is some indication of $\mathrm{T}_{\mathrm{P}}$ up to $1650^{\circ} \mathrm{C}$ at this location at $61 \mathrm{Ma}$. Data for contemporaneous 633 lavas related to the SDRS of East Greenland gives $\mathrm{T}_{\mathrm{P}} \sim 1456^{\circ} \mathrm{C}$ suggesting a spatial gradient 634 in $\mathrm{T}_{\mathrm{P}}$. Magmatism in the BPIP required $\mathrm{T}_{\mathrm{P}} \sim 1500^{\circ} \mathrm{C}$ at $58-60 \mathrm{Ma}$, with the possibility that the 635 main plateau-forming lava sequences are slightly lower than this at $\mathrm{T}_{\mathrm{P}} \sim 1480^{\circ} \mathrm{C}$. Latest 636 Palaeocene and earliest Eocene (55-57 Ma) magmatism in East Greenland required $\mathrm{T}_{\mathrm{P}} \sim$ $6371538^{\circ} \mathrm{C}$, whereas contemporaneous lavas within the upper formations of the FIBG required $638 \mathrm{~T}_{\mathrm{P}} \sim 1519^{\circ} \mathrm{C}$. Modern Iceland has a bimodal distribution of $\mathrm{T}_{\mathrm{P}}$, with rift-flank magmatism 639 requiring a lower $\mathrm{T}_{\mathrm{P}}\left(\sim 1450^{\circ} \mathrm{C}\right)$ than rift-zone magmatism $\left(\sim 1500^{\circ} \mathrm{C}\right)$. For the NAIP as a 640 whole the dominant control on $\mathrm{T}_{\mathrm{P}}$ appears to be the proximity to the plume centre, although 641 thermal pulsing of the plume cannot be ruled out based in the current data set, and may be the 642 reason for $\mathrm{T}_{\mathrm{P}}$ variations in Iceland at present-day.

643 Variations in the extent of melting required for the generation of picrites in West 644 Greenland was controlled by the depth to the base of the lithosphere. Melting beneath Disko 645 Island ceased at $\sim 60 \mathrm{~km}$ deeper that at Baffin Island, the latter having melt column 646 characteristics similar to modern Iceland, but with $\mathrm{T}_{\mathrm{P}}$ approximately $50^{\circ} \mathrm{C}$ hotter. Integration 647 of the results of major element modelling with data for the REE, shows that convex-upwards 648 REE profiles $\left([\mathrm{La} / \mathrm{Sm}]_{\mathrm{N}}<1.0\right.$ and $\left.[\mathrm{Tb} / \mathrm{Yb}]_{\mathrm{N}}>1.0\right)$ can be generated from a LREE-depleted 649 source, at $\mathrm{T}_{\mathrm{P}} \geq 1480^{\circ} \mathrm{C}$ where the base of the lithosphere is $\geq 65 \mathrm{~km}$ in depth. The recognition 650 of such REE profiles is therefore pressure and $T_{P}$ specific. 
$651 \quad$ ACKNOWLEDGEMENTS

652 The authors wish to thank Claude Herzberg, Estaban Gazel and an anonymous reviewer

653 for thoughtful and constructive reviews.

654 
655 References cited.

656 Adria, P., Hirschmann, M.M., Withers, A.C. \& Tenner, T.J. (2012). $\mathrm{H}_{2} \mathrm{O}$ storage capacity of 657 olivine at 5-8GPa and consequences for dehydration partial melting of the upper mantle. 658 Earth and Planetary Science Letters, 345-358, 104-116.

659 Albarède, F. (1992). How deep do common basaltic magmas form and differentiate? Journal 660 of Geophysical Research, 97, 10997-11009.

661 Archer, S.A., Bergman, S.C., Illiffe, J., Murphy, C.M. \& Thorton, M. (2005). Palaeogene 662 igneous rocks reveal new insights into the geodynamic evolution and petroleum potential 663 of the Rockall Trough, NE Atlantic Margin. Basin Research, 17, 171-201.

664 Baker, M.B. \& Beckett, J.R. (1999). The origin of abyssal peridotites: a reinterpretation of 665 constraints based on primary bulk compositions. Earth and Planetary Science Letters, $666 \quad 171,49-61$.

667 Barnhoorn, A., van der Wal, W. \& Drury, M.R. (2011). Upper mantle viscosity and 668 lithospheric thickness under Iceland. Journal of Geodynamics, 52, 260-270.

669 Barrat, J.A. \& Nesbitt, R.W. 1996. Geochemistry of Tertiary volcnaism of Northern Ireland. 670 Chemical Geology, 129, 15-38.

671 Chambers, L.M. \& Pringle, M.S. (2001). Age and duration of activity at the Isle of Mull 672 Tertiary igneous centre, Scotland, and confirmation of the existence of subchrons during 673 Anomaly 26r. Earth and Planetary Science Letters, 193, 333-345.

674 Coogan, L.A., Saunders, A.D. \& Wilson, R.N. (2014). Aluminium-in-olivine thermometry of 675 primitive basalts: Evidence of an anomalously hot mantle source for large igneous 676 provinces. Chemical Geology, 368, 1-10.

677 Courtier, A.M. (2007). Correlation of seismic and petrological thermometers suggests deep 678 thermal anomalies beneath hotspots, Earth and Planetary Science Letters, 264, 308-316.

679 Cramer, E.L., Sherlock, S.C., Halton, A.M., Blake, S., Barry, T.L., Kelley, S.P. \& Jolley, 680 D.W. (2013). Which age is the true age? Unravelling within-flow ${ }^{40} \mathrm{Ar} /{ }^{39} \mathrm{Ar}$ age variations 681 in Faroe Islands basalt lavas. Goldschmidt Conference Abstract, Florence, Italy.

682 Dale, C.W., Pearson, D.G., Starkey, N.A., Stuart, F.M., Ellam, R.M., Larsen, L.M., Fitton J.G 683 \& Macpherson, C.G. (2009). Osmium isotopes in Baffin Island and West Greenland 684 picrites: Implications for the ${ }^{187} \mathrm{Os} /{ }^{188} \mathrm{Os}$ composition of the convecting mantle and the 685 nature of high ${ }^{3} \mathrm{He} /{ }^{4} \mathrm{He}$ mantle. Earth and Planetary Science Letters, 278, 267-277.

686 Dasgupta, R., Hirschmann, M.M. \& Smith, N.D. (2007). Partial melting experiments on 687 peridotite $+\mathrm{CO}_{2}$ at $3 \mathrm{GPa}$ and genesis of alkalic ocean island basalts, Journal of 688 Petrology, 48, 2093-2124. 
Dickin, A.P., Jones, N.W., Thirlwall, M.F. \& Thompson, R.N. (1987). A Ce/Nd isotope study

690

691

692

693

694

695

696

697

698

699

700

701

702

703

704

705

706

707

708

709

710

711

712

713

714

715

716

717

718

719

720 of crustal contamination processes affecting Paleocene magmas in Skye, Northwest Scotland. Contributions to Mineralogy \& Petrology, 96, 455-464.

Ebdon, C.C., Granger, P.J., Johnson, H.D. \& Evans, A.M. (1995). Early Tertiary evolution and sequence stratigraphy of the Faeroe-Shetland Basin: implications for hydrocarbon prospectivity. In: Scrutton, R. A., Stoker, M. S., Shimmield, G. B. \& Tudhope, A. W. (eds), 1995, The Tectonics, Sedimentation and Palaeoceanography of the North Atlantic Region, Geological Society Special Publications, 90, 51-69.

Fitton, J.G., Saunders, A.D., Norry, M.J., Hardarson, B.S. \& Taylor R.N. (1997). Thermal and chemical structure of the Iceland plume. Earth and Planetary Science Letters, 153, 197-208.

Foulger, G.R. (2012). Are 'hot spots' hot spots ? Journal of Geodynamics, 58, 1-28.

Fowler, S.J., Bohrson, W.A. \& Spera, F.J. (2003). Magmatic Evolution of the Skye Igneous Centre, Western Scotland: Modelling of Assimilation, Recharge and Fractional Crystallization. Journal of Petrology, 45, 2481-2505.

Ganerød, M., Smethurst, M.A., Torsvik, T.H., Prestvik, T., Rousse, S., McKenna, C., van Hinsbergen, D.J.J. \& Hendriks B.W.H. (2010). The North Atlantic Igneous Province reconstructed and its relation to the Plume Generation Zone: the Antrim Lava Group revisited. Geophysical Journal International, 182, 183-202.

Gazel, E., Hoernle, K., Carr, M.J., Herzberg, C, Saginor, I., van den Bogaard, P., Hauff, F., Feigenson, M., \& Swisher III, C., (2011). Plume-subduction interaction in southern Central America: Mantle upwelling and slab melting. Lithos, 121, 117-134.

Gill, R.C.O., Pedersen, A.K. \& Larsen, J.G. (1992). Tertiary picrites in West Greenland: Melting at the periphery of a plume? In: Storey, B. C., Alabaster, T. \& Pankhurst, R. J. (eds) Magmatism and the causes of Continental Break-Up Geological Society, London, Special Publications, 68, 335-348.

Hamilton, M.A., Pearson, D.G., Thompson, R.N., Kelley, S.P. \& Emeleus, C.H. (1998). Rapid eruption of Skye lavas inferred from precise $\mathrm{U}-\mathrm{Pb}$ and $\mathrm{Ar}-\mathrm{Ar}$ dating of the Rum and Cuillin plutonic complexes. Nature, 384, 260-263.

Hards,V. L., Kempton, P. D., Thompson, R. N. \& Greenwood, P. B. (2000). The magmatic evolution of the Snaefell volcanic centre: an example of volcanism during incipient rifting in Iceland. Journal of Volcanology and Geothermal Research 99, 97-121. 
721 Hardarson, B.S., Fitton, J.G, Ellam, R.M. \& Pringle, M.S., (1997). Rift relocation - a

722 geochemical and geochronological investigation of a palaeo-rift in northwest Iceland, 723 Earth and Planetary Science Letters, 153, 181-196.

724 Herzberg, C. (2004a). Partial Crystallization of Mid-Ocean Ridge Basalts in the Crust and 725 Mantle. Journal of Petrology, 45, 2389-2405.

726 Herzberg, C. (2004b). Geodynamic information in peridotite petrology. Journal of Petrology $727 \quad 45,2507-2530$.

728 Herzberg, C. (2006). Petrology and thermal structure of the Hawaiian plume from Mauna 729 Kea volcano. Nature, 444, 605-609.

730 Herzberg, C. \& O’Hara, M.J. (2002). Plume-associated ultramafic magmas of Phanerozoic 731 age, Journal of Petrology, 43, 1857-1883.

732 Herzberg, C. \& Asimow, P.D. (2008). Petrology of some oceanic island basalts: 733 PRIMELT2.XLS software for primary magma calculation. Geochemistry, Geophysics, 734 Geosystems, 9.

735 Herzberg, C. \& Gazel, E. (2009). Petrological evidence for secular cooling in mantle plumes. Nature, 458, 619-623.

Herzberg, C. \& Asimow, P.D. (2015). PRIMELT3 MEGA.XLSM software for primary magma calculation: Peridotite primary magma $\mathrm{MgO}$ contents from the liquidus to the solidus. Geochemistry, Geophysics, Geosystems, 16, 563-578.

Herzberg, C., Asimow, P.D., Arndt, N., Niu, Y., Lesher, C.M., Fitton, J.G., Cheadle, M.J. \& Saunders, A.D. (2007). Temperatures in ambient mantle and plumes: Constraints from basalts, picrites, and komatiites. Geochemistry, Geophysics, Geosystems, 8, 1-34.

Hole, M.J. \& Saunders, A.D. (1996). The generation of small melt-fractions in truncated melt columns: Constraints from magmas erupted above slab windows and implications for MORB genesis. Mineralogical Magazine, 60, 173-189.

Hole, M.J. (2015). The generation of continental flood basalts by decompression melting of internally heated mantle. Geology, 43, 311-314.

Hole. M.J., Millett, J.M., Rogers, N.W. \& Jolley, D.W. (2015). Rifting and mafic magmatism in the Hebridean basins. Journal of the Geological Society, London, 172, 218-236.

Howell, S.M., Garrett, I., Breivik, A.J., Rai, A., Mjelde, R., Hanan, B., Sayit, K. \& Vogt, P. (2014). The origin of the asymmetry in the Iceland hotspot along the Mid-Atlantic Ridge from continental break-up to present day. Earth and Planetary Science Letters, 392, 143 153. 
Hunt, A.C., Parkinson, I.J., Harris, N.B.W., Barry, T.L., Rogers, N.W. \& Yondon, M. (2012).

755

756

757

758

759

760

761

762

763

764

765

766

767

768

769

770

771

772

773

774

775

776

777

778

779

780

781

782

783

784

785

786

787

Cenozoic volcanism on the Hangai Dome,central Mongolia: geochemical evidence for changing melt sources and implications for mechanisms of melting. Journal of Petrology, 53, 1913-1942.

Jamtveit, B., Brooker, R., Brooks, K., Larsen, L.M. \& Pedersen, T. (2001). The water content of olivines frojm the North Atlantic Volcanic Province. Earth and Planetary Science Letters, 186, 401-415.

Jolley, D.W. \& Bell, B.R. (1997). Application of palynological data to the chronology of the Palaeogene lava fields of the British Province: Implications for magmatic stratigraphy. Journal of the Geological Society, London, 154, 701-708.

Kent, R.W. \& Fitton, J.G. (2000). Mantle sources and melting dynamics in the British Palaeogene Igneous Province. Journal of Petrology, 41, 1023-1040.

Kerr, A.C., Kent, R.W., Thomson, B.A., Seedhouse, J.K. \& Donaldson, C.H. (1999). Geochemical Evolution of the Tertiary Mull Volcano, Western Scotland. Journal of Petrology, 40, 873-908.

Klein, E.M. \& Langmuir, C.H. 1987. Global correlations of ocean ridge basalt chemistry with axial depth and crustal thickness. Journal of Geophysical Research, 92, 8089-8115.

Larsen L. M. \& Pedersen A. K. (2000). Processes in high-Mg, high-T magmas: evidence from olivine, chromite and glass in Paleogene picrites from West Greenland. Journal of Petrology, 41, 1071-1098

Larsen, L.M. \& Pedersen, A.K. (2009). Petrology of the Paleocene Picrites and Flood Basalts on Disko and Nuussuaq, West Greenland. Journal of Petrology, 50, 1667-1711.

Larsen, L.M., Waagstein, R., Pedersen, A. K. \& Storey, M. (1999). Trans-Atlantic correlation of the Palaeogene volcanic successions in the Faeroe Islands and East Greenland. Journal of the Geological Society, 156, 1081-1095.

Larsen, L.M., Heaman, L.M., Creaser, R.A., Duncan, R.A., Frei, R. \& Hutchison, M. (2009) Tectonomagmatic events during stretching and basin formation in the Labrador Sea and the Davis Strait: evidence from age and composition of Mesozoic to Palaeogene dyke swarms in West Greenland. Journal of the Geological Society, London, 166, 999-1012.

Larsen, L.M., Oedersen, A.K., Tegner, C. \& Duncan R.A. (2014). Eocene to Miocene igneous activity in NE Greenland: northward younging of magmatism along the East Greenland margin. Journal of the Geological Society, London, 171, 539-553.

Larsen L.M., Pedersen, A.K., Tegners, C., Duncan, R.A., Hald, N. \& Larsen, J.G. (2015). Age of Tertiary volcanic rocks on the West Greenland continental margin: volcanic 
802

803

804

805

806

807

808

809

810

811

812

813

814

815

816

817

818

819

evolution and event correlation to other parts of the North Atlantic Igneous Province. Geological Magazine. doi:10.1017/S0016756815000515

Lawver, L.A. \& Müller, R.D. (1994). The Iceland hotspot track. Geology, 22, 311-314.

Lee, C-T. A., Lenardic, A., Cooper, C.M., Niu, F. \& Levander, A. (2005). The role of chemical boundary layers in regulating the thickness of continental and oceanic thermal boundary layers. Earth and Planetary Science Letters, 230, 379-395.

Lee, C-T. A., Luffi, P., Plank, T., Dalton, H. \& Leeman, W.P. (2009). Constraints on the depths and temperatures of basaltic magma generation on Earth and other terrestrial planets using new thermobarometers for mafic magmas. Earth and Planetary Science Letters, 279, 20-33.

Lightfoot, P.C., Hawkesworth, C.J., Olshefsky, K., Green, T. Doherty, W \& Keays, R.R. 1997. Geochemistry of Tertiary tholeiites and picrites from Qeqertarssuaq (Disko Island) and Nuussuaq, West Greenland with implications for the mineral potential of comagmatic intrusions. Contributions to Mineralogy and Petrology, 128, 139-163.

Maclennan, J., McKenzie, D. \& Gronvøld, K. (2001). Plume-driven upwelling under central Iceland. Earth and Planetary Science Letters, 194, 67-82.

Mattsson, H. B. \& Oskarsson, N. (2005). Petrogenesis of alkaline basalts at the tip of a propagating rift: evidence from the Heimey volcanic center, south Iceland. Journal of Volcanology and Geothermal Research, 147, 245-267.

Mihalffy, P., Steinberger, B. \& Schmeling, H. 2008. The effect of the large-scale mantle flow field on the Iceland hotspot track. Tectonophysics, 447, 5-18

Millett, J.M., Hole, M.J., Jolley, D.W., Schofield, N. \& Campbell, E. 2015. Frontier exploration and the North Atlantic Igneous Province: new insights from a $2.6 \mathrm{~km}$ offshore volcanic sequence in the NE Faroe-Shetland Basin. Journal of the Geological Society, London. doi:10.1144/jgs2015-069.

Murton, B.J., Taylor, R.N. \& Thirlwall, M.F. (2002). Plume-ridge interaction: a geochemical perspective from the Reykjanes Ridge. Journal of Petrology, 43, 1155-1176.

Nichols, A.R.L., Carroll, M.R. \& Hoskulsson, A. (2002). Is the Iceland hot spot also wet? Evidence from the water contents of undegassed submarine and subglacial pillow basalts. Earth and Planetary Science Letters, 202, 77-87.

Nielsen, S.B., Stephenson, R.A. \& Thomsen, E. (2007). Dynamics of Mid-Palaeocene North Atlantic rifting linked with European intra-plate deformations. Nature, 450, 1071-1074 
820 Parnell-Turner, R.E., White, N.J., Maclennan, J, Henstock, T.J., Murton, B.J. \& Jones, S.M.

821

822

823

824

825

826

827

828

829

830

831

832

833

834

835

836

837

838

839

840

841

842

843

844

845

846

847

848

849

850

851

852
(2013). Crustal manifestations of a hot transient pulse at $60^{\circ} \mathrm{N}$ beneath the Mid-Atlantic Ridge. Earth and Planetary Science Letters, 363, 109-120.

Parnell-Turner, R., White, N., Henstock, T, Murton, B., Maclennan, J., \& Jones, S.M., (2014). A continuous 55-million-year record of transient mantle plume activity beneath Iceland. Nature Geoscience, 7, 914-919.

Passey, S.R. \& Jolley, D.W. (2009). A revised lithostratigraphic nomenclature for the Palaeogene Faroe Islands Basalt Group, NE Atlantic Ocean. Earth and Environmental Science Transactions of the Royal Society of Edinburgh, 99, 127-158.

Pearson, D.G., Emeleus, C.H. \& Kelley, S.P. (1996). Precise ${ }^{40} \mathrm{Ar} /{ }^{39} \mathrm{Ar}$ age for the initiation of Palaeogene volcanism in the Inner Hebrides and its regional significance. Journal of the Geological Society, London, 158, 815-818.

Peate, D.W., Barker, A.K., Riishuus, M.S. \& Andreasen, R. (2008). Temporal variations in crustal assimilation of magma suites in the East Greenland flood basalt province: Tracking the evolution of magmatic plumbing systems. Lithos, 102, 179-197.

Peate, D.W., Breddam, K., Baker, J.A., Kurz, M.D., Barker, A.K., Prestvik, T., Grassinaeu, N., \& Skogvaard, C. (2010). Compositional characteristics and spatial distribution of enriched Icelandic mantle components. Journal of Petrology, 51, 1447-1475.

Peate, D.W., Peat, I.U., Rowe, M.C., Thompson, J.M. \& Kerr, A.C. (2012). Petrogenesis of High-MgO lavas of the Lower Mull Plateau Lava Formation, Scotland: insights from melt inclusions. Journal of Petrology, 53, 1867-1886

Peslier, A.A. \& Bizimis, M. (2015). Water in Hawaiian peridotite: A case study for a dry metasomatized oceanic mantle lithosphere. Geochemistry, Geophysics, Geosystems, 16, 1211-1232.

Poore, H.R., White, N. \& Jones, S. 2009. A Neogene chronology of Iceland plume activity from V-shaped ridges. Earth and Planetary Science Letters, 283, 1-13.

Putirka, K.D. (2008). Thermometers and Barometers for Volcanic Systems. Reviews in Mineralogy \& Petrology, 69, 61-120.

Putirka, K.D., Perfit, M., Ryerson, F.J. \& Jackson, M.G. (2007). Ambient and excess mantle temperatures, olivine thermometry, and active vs. passive upwelling. Chemical Geology, 241, 177-206.

Robinson, J.A.C. \& Wood, B.J. (1998). The depth of the spinel to garnet transition at the peridotite solidus. Earth and Planetary Science Letters, 164, 277-284. 
853 Saunders, A.D., Fitton J.G., Kerr, A.C., Norry, M.J. \& Kent, R.W. (1997). The North Atlantic 854 Igneous Province. In: Mahoney, J.J. \& Coffin, M.F. (eds) Large Igneous Provinces: 855 Continental, Oceanic and Planetary Volcanism. Geophysical Monograph, American 856 Geophysical Union, 100, 45-93.

857 Scarrow, J.H. \& Cox, K.G. (1995). Basalts generated by decompressive adiabatic melting of 858 a mantle plume: a case study from the Isle of Skye, NW Scotland. Journal of Petrology, 859 36, 3-22.

860 Scarrow, J.H., Curran, J.M. \& Kerr, A.C. (2000). Major element records of variable plume 861 involvement in the North Atlantic Province Tertiary Flood Basalts. Journal of Petrology 862 41, 1155-1176.

Shorttle, O., Maclennan, J. \& Lambart, S. (2014). Quantifying lithological variability in the mantle. Earth \& Planetary Science Letters, 395, 24-40.

Starkey, A.A., Stuart, F.M., Ellam, R.M., Fitton J.G., S, Basu \& Larsen L. M. 2009. Helium isotopes in early Iceland plume picrites: constraints on the composition of high ${ }^{3} \mathrm{He} /{ }^{4} \mathrm{He}$ mantle. Earth and Planetary Science Letters, 277, 91-100.

Sun, S-S. \& McDonough, W.F. (1988). Chemical and isotopic systematics of oceanic basalts: implications for mantle composition and processes. In: Saunders, A. D. \& Norry, M. J. (eds) Magmatism in the ocean basins. Geological Society, London, Special Publications, 42, 313-345.

Tegner, C., Lesher, C.E., Larsen, L.M. \& Watt, W.S. (1998). Evidence from the rare-earthelement record of mantle melting for cooling of the Tertiary Iceland plume. Nature, 395, $591-594$.

Thompson, R.N. \& Morrison, M.A. (1988). Asthenospheric and lower lithospheric mantle contributions to continental extensional magmatism: an example from the British Tertiary Province. Chemical Geology, 68, 1-15.

Thompson, R.N., Dickin, A.P., Gibson, I.L. \& Morrison, M.A. (1982). Elemental fingerprints of isotopic contamination of Hebridean Palaeocene mantle-derived magmas by Archaean Sial. Contributions to Mineralogy and Petrology, 79, 159-168.

Thompson, R.N., Morrison, M.A., Dickin, A.P., Gibson, I.L. \& Harmon, R.S. (1986). Two contrasting styles of interaction between basic magmas and continental crust in the British Tertiary Volcanic Province. Journal of Geophysical Research, 91, 5985-5997.

Trela, J., Vidito, C., Gazel, E., Herzberg, C., Class, C., Whalen, W., Jicha, B., Bizimis, M. \& Alvarado, G.E. (2015). Recycled crust in the Galpagos plume source at $70 \mathrm{Ma}$; implications for plume evolution. Earth and Planetary Science Letters, 425, 268-277. 
887 Waight, T.E. \& Baker, J.A. (2012). Depleted basaltic lavas from the Proto-Iceland plume, 888 central East Greenland. Journal of Petrology, 53, 1569-1596.

889 Walter, M. J. 1998. Melting of garnet peridotite and the origin of komatiite and depleted 890 lithosphere, Journal of Petrology, 39, 29-60.

891 Yaxley, G.M., Kamanetsky, V.S., Kamanestsky, M., Norman, M.D. \& Francis, D. (2004). 892 Origins of compositional heterogeneity in olivine-hosted melt inclusions from the Baffin 893 Island picrites. Contributions to Mineralogy ans Petrology, 148, 426-442. 
895 Figure Captions.

896 Fig. 1 a) (a) Map of the continental shelf west of the British Isles showing the position of 897 onshore and offshore igneous centres and dyke swarms. Pecked lines labelled "Lawver \& 898 Muller" and "Mihalffy et al." are the extents of the plume influence according to Lawver \& 899 Müller (1994) and Mihalffy et al. (2008). After Hole et al. (2015). b) reconstruction of the 900 North Atlantic region at about 65 Ma giving the locations of places referred to in the text.

901 Fig. 2. Stratigraphy of the BPIP and adjacent areas from 65-50 Ma, modified and updated 902 after Jolley \& Bell (2002). Depositional sequences labelled T10 to T60 are from Ebdon et al. 903 (1995). Absolute ages; Skye and Rum intrusions, Hamilton et al. (1998); 164/170-1 sills, 904 Archer et al. (2005); Antrim basalts, Ganerod et al. (2009); Eigg lavas, Pearson et al. (1996); 905 Greenland, Larsen et al. (2009; 2014; 2015).

906 Fig. 3 a) Schematic pressure-temperature diagram illustrating the petrogenesis of an olivine907 phyric basalt (BI/CS/8; Dale et al., 2009) with $9.7 \mathrm{wt} \% \mathrm{MgO}$ which fractionated 28\% olivine 908 and erupted with a liquidus temperature of $\sim 1420^{\circ} \mathrm{C}$. The primary magma to this basalt is 909 calculated to contain $19.0 \mathrm{wt} \% \mathrm{MgO}$, requiring $\mathrm{T}_{\mathrm{P}} \sim 1540^{\circ} \mathrm{C} . \mathrm{P} i=4.2 \mathrm{GPa}$, and is calculated 910 from the intersection of the dry peridotite solidus and the $1540^{\circ} \mathrm{C}$ adiabat. The primary 911 magma ascended along the olivine liquidus as indicated by the arrows, which also 912 corresponds to the $19.0 \mathrm{wt} \% \mathrm{MgO}$ isopleth. The extent of melting, FAFM $\sim 0.30$, is 913 calculated from phase equilibria. The final pressure of melting, $\mathrm{P} f$, is estimated to be $1.9 \mathrm{GPa}$ 914 for this sample. The mean pressure of melting $\mathrm{P} m=2.6 \mathrm{GPa}$ at $1550^{\circ} \mathrm{C}$. Note that initial 915 melting takes place in equilibrium with garnet peridotite, but the majority of melting takes 916 place in the spinel stability field of the upper-mantle. Pi was calculated according to the 917 schemes of Herzberg \& Gazel (2009) and Gazel et al. (2011) and P $m$ was calculated using 918 the method of Lee et al. (2009). Details of $\mathrm{P} f$ calculations are given in Electronic Appendix 2. 919 The dry peridotite solidus is taken from Herzberg \& Asimow (2015) and numbers in italics 920 represent $\mathrm{MgO}$ content of primary magmas formed along the solidus, which are the starting 921 points for the $\mathrm{MgO}$ isopleths. 'Garnet in' and 'spinel out' boundaries are from Robinson \& 922 Wood (1998).

923 Fig. 4. a) $\mathrm{FeO}$ versus $\mathrm{MgO}$ for modelled primary magma compositions showing initial 924 pressure of melting ( $\mathrm{P} i$; pecked lines with arrows) final pressure of melting ( $\mathrm{P} f$; solid lines) 925 and melt fraction ( $F-A F M$; thin pecked lines) for melting of mantle peridotite KR-4003. Note 926 that Baffin Island primary magmas mostly have $\mathrm{P} f<2.0$ whereas Disko Island have $\mathrm{P} f \sim 2.0$ 
927 to $>3.0 \mathrm{GPa}$. Baffin Island primary magmas occupy a similar position in this diagram to 928 those for the Ontong-Java Plateau. Primary magma compositions are from this study, 929 Herzberg \& Gazel (2009) and Hole (2015). b) molecular projection of primary magma 930 compositions onto the plane olivine-anorthite-quartz (Ol-An-Qz) from or towards diopside 931 ([Di]) showing the stability fields for garnet peridotite, spinel peridotite and harzburgite in 932 relationship to extent of melting $(F A F M)$. Note that Baffin Island primary magmas mostly 933 separated from a harzburgite residue, whereas Disko Island primary magmas mostly 934 separated from a garnet peridotite residue, requiring Baffin Island basalts to have lower $\mathrm{P} f$ 935 than Disko Island. Sample BI/CS/8 which is shown in Fig. 3, is indicated in both a) and b) 936 and its calculated primary magma composition is consistent with final separation from a 937 harzburgite residue. Both a) and b) are after Herzberg \& Asimow (2008; 2015). Further details of these figures are given in Electronic Appendix 2 and 3.

939 Fig. 5. Final pressure of melting $(\mathrm{P} f)$ versus temperature $\left(\mathrm{T}^{\circ} \mathrm{C}\right)$ for NAIP basalts which yield 940 PRIMELT solutions for melting of dry mantle peridotite. Dotted lines are olivine liquidi with 941 the potential temperature indicated. Pecked lines are contours of constant $\mathrm{MgO}$ in the primary 942 magma with wt $\% \mathrm{MgO}$ indicated by crosses on the peridotite solidus. a) Vaigat Formation 943 picrites and basalts from Disko Island and Baffin Island; b) British Palaeocene tholeiites and 944 basalts along with Faroe Islands Basalt Group. Filled diamonds are PRIMELT solutions 945 derived from melt inclusions trapped in olivine phenocrysts in MPLF lavas; c) Iceland rift 946 zones and rift flanks. Data and sources are given in the electronic Appendix 4.

947 Fig. 6. Histograms showing $\mathrm{T}_{\mathrm{P}}$ distributions for basalts of the NAIP. $1548 \pm 32^{\circ} \mathrm{C}$ is the mean $948 \mathrm{~T}_{\mathrm{P}}$ and $2 \sigma$ for Disko Island.

949 Fig.7. Histograms of accumulated melt-fraction produced $(F-A F M)$ for NAIP primary 950 magmas.

951 Fig. 8. Histograms of mean pressure of melting $(\mathrm{P} m)$ for NAIP magmas. The cross-hatched 952 area represents the garnet-spinel transition in the upper mantle. The range of $\mathrm{P} m$ for 953 Siqueiros MORB is shown in the bottom frames for reference. P $m$ was calculated using the 954 scheme of Lee et al. (2009).

955 Fig. 9. Diagrammatical representations of melting columns for various locations in the NAIP, 956 MORB from the Siqueiros Fracture Zone, and basalts from the Ontong-Java Plateau. Pi, P $f$ 957 and $\mathrm{P} m$ are melting column-averaged data for the location named. The garnet-in boundary 958 and garnet-spinel transition are taken from Robinson \& Wood (1998) and are those used by 
959 PRIMELT3. Melting with harzburgite as the residue is not directly correlated with pressure 960 of melting but with extent of melting and so the harzburgite fields are schematic. Note that 961 Siqueiros MORB, Iceland rift-flanks, BPIP and Faroe-Shetland Basin melting columns have $962 \mathrm{P} f \approx \mathrm{P} m$.

963 Fig. 10. Chondrite-normalized (Sun \& McDonough, 1988) REE abundances for NAIP basalts 964 with $[\mathrm{La} / \mathrm{Sm}]_{\mathrm{N}}<1.0$ and $\Delta \mathrm{Nb}<0$. a) samples with a garnet peridotite residue; b) samples 965 with a spinel peridotite residue and $\mathrm{P} f=2.8-3.1 \mathrm{GPa} ; \mathrm{c})$ samples with a harzburgite residue 966 and $\mathrm{P} f<2.8 \mathrm{GPa}$; d) samples from the BPIP with convex-upwards REE profiles consistent 967 with melting in the garnet-spinel transition of the upper mantle but for which no PRIMELT 968 solutions are available. Figures parentheses after the sample names are $\mathrm{T}_{\mathrm{P}}$ and $F$ respectively. 969 The pecked field on each diagram is the range of REE abundances for melting leaving a 970 harzburgite residue at $\mathrm{P} m<2.8 \mathrm{GPa}$. Data sources for BPIP samples; Antrim Plateau, Barrat 971 \& Nesbitt (1996); MPLF, Kerr et al. (1999); CMT, Hole et al. (2015) and Kent \& Fitton 972 (2000).

973 Fig. 11. Plot of $[\mathrm{Tb} / \mathrm{Yb}]_{\mathrm{N}}$ versus $[\mathrm{La} / \mathrm{Yb}]_{\mathrm{N}}$ for a) all Baffin Island and Disko Island depleted $974(\Delta \mathrm{Nb}<0)$ basalts. Data sources; Baffin Island, Dale et al. (2009); Disko Island, Lightfoot et 975 al. (1997) and Larsen \& Pedersen (2000). b) NAIP depleted basalts for which PRIMELT 976 solutions are available, indexed by the mineralogy of the residue with which they were in 977 equilibrium at the time of extraction. c) NAIP samples for which no PRIMELT solutions are 978 available. In all diagrams, continuous lines with crosses are melting trajectories garnet and 979 spinel peridotite for a starting composition the same as that for 'non-plume' MAR MORB 980 basalts (Hole et al. 2015; Murton et al. 2002) with crosses are at 1\% melt intervals. After 981 Hunt et al. (2012). Horizontal contours for $F$ are schematic only. As a first approximation, 982 our PRIMELT database shows that for $\mathrm{T}_{\mathrm{P}}=1500-1550^{\circ} \mathrm{C}$ melting occurs at a melt column983 averaged rate of $\sim 13 \% \mathrm{GPa}^{-1}$. 


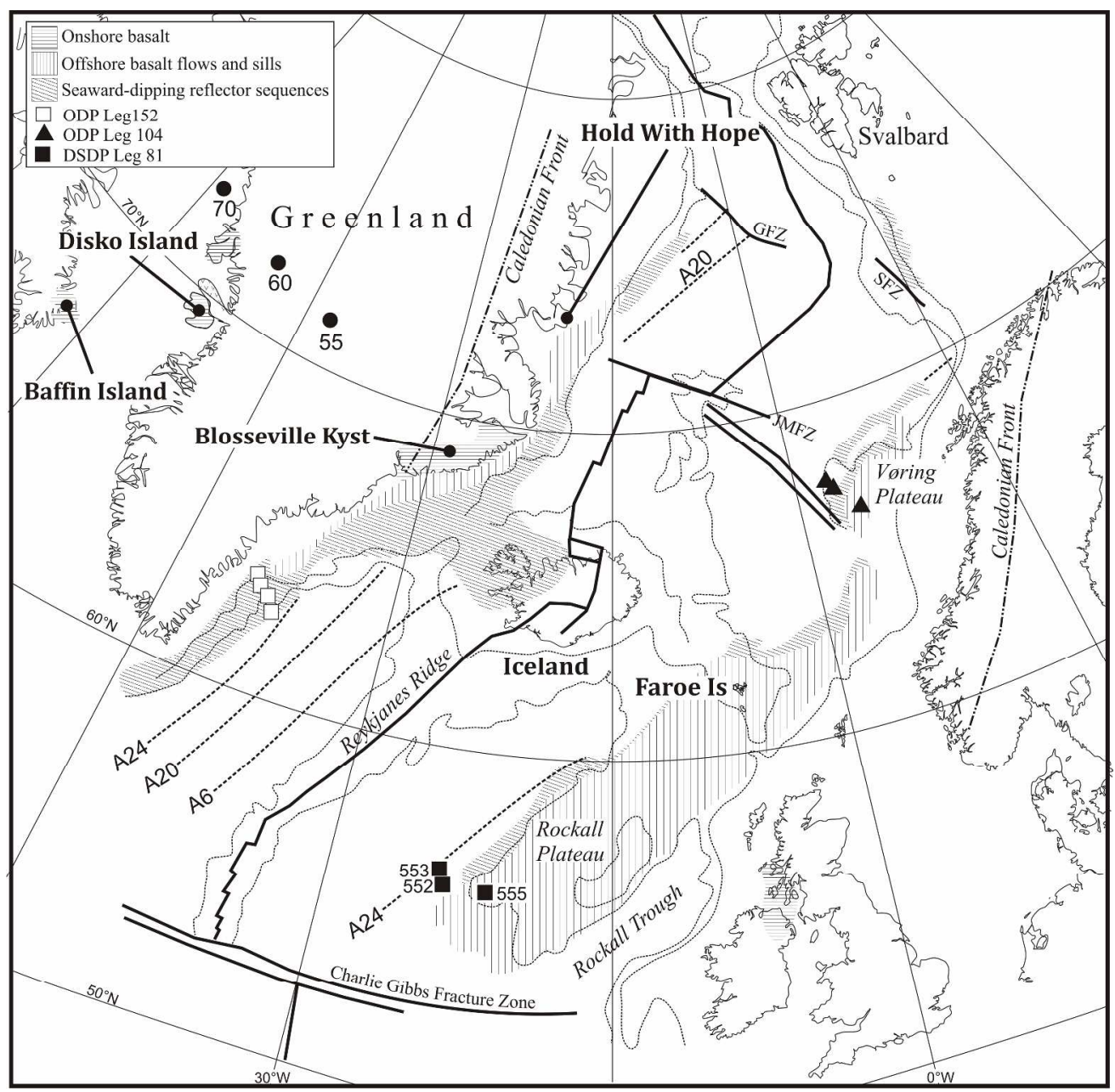

$268 \times 261 \mathrm{~mm}(300 \times 300$ DPI $)$ 


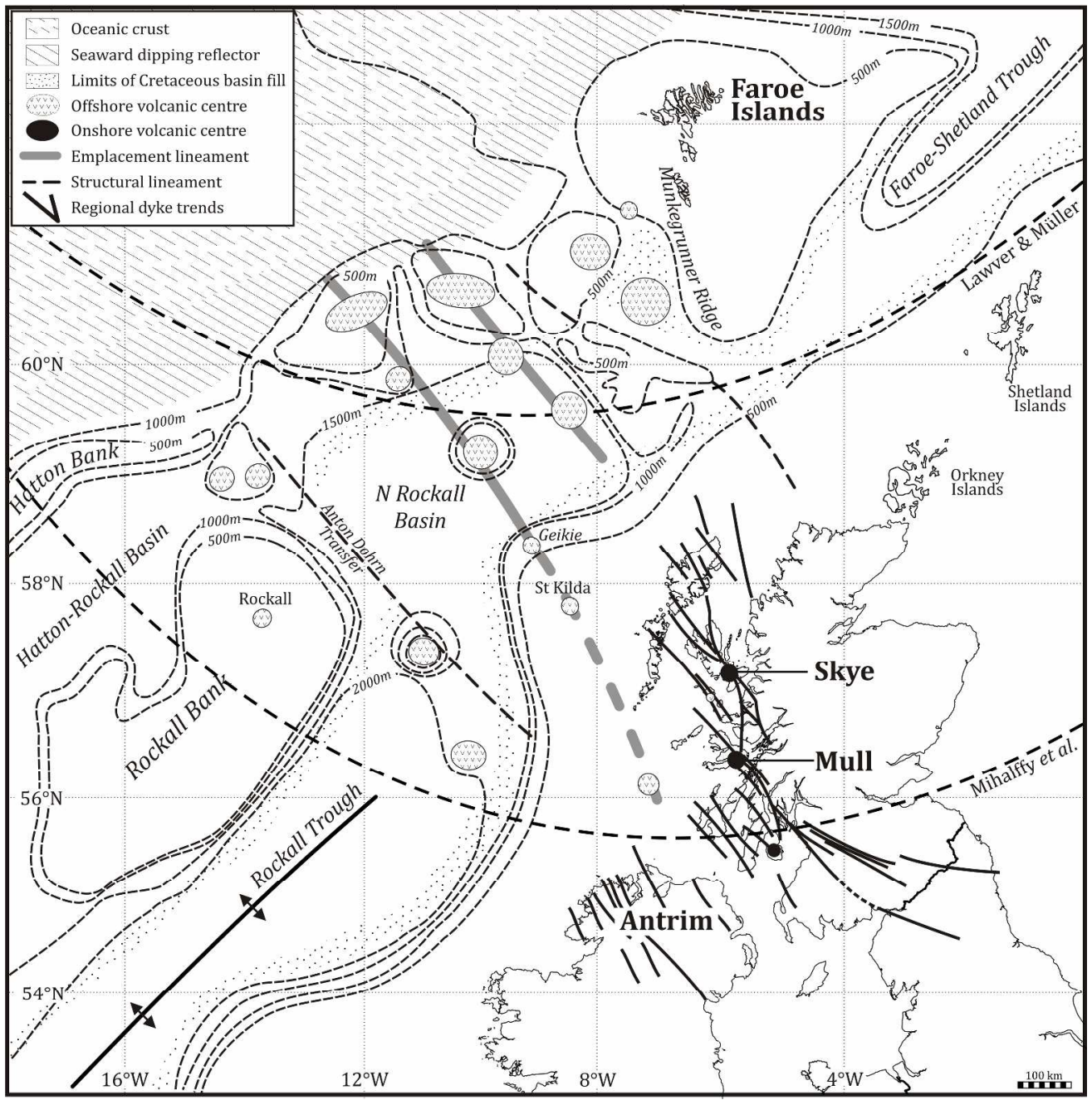

$267 \times 270 \mathrm{~mm}(300 \times 300 \mathrm{DPI})$ 


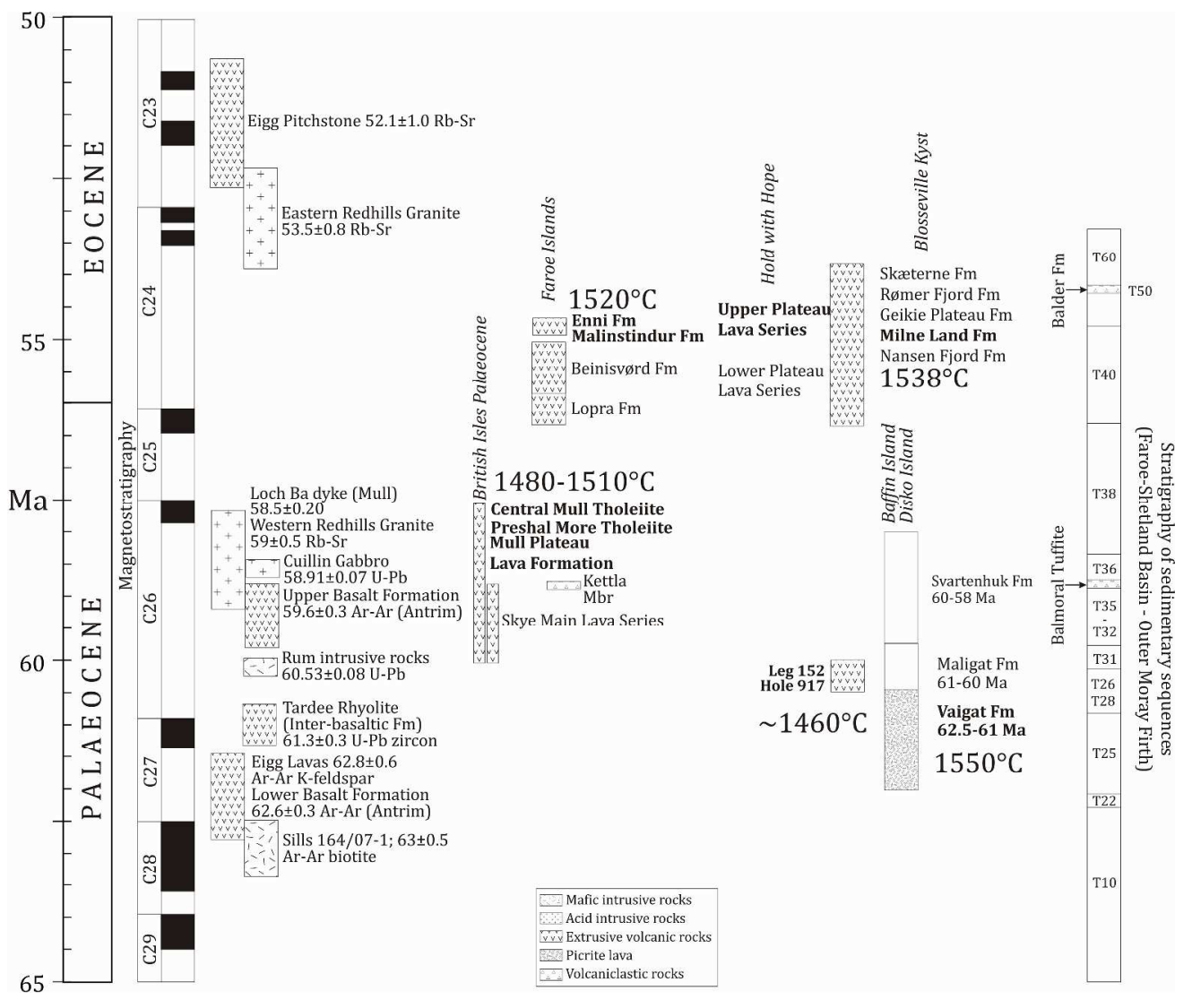

$521 \times 437 \mathrm{~mm}(300 \times 300$ DPI $)$ 


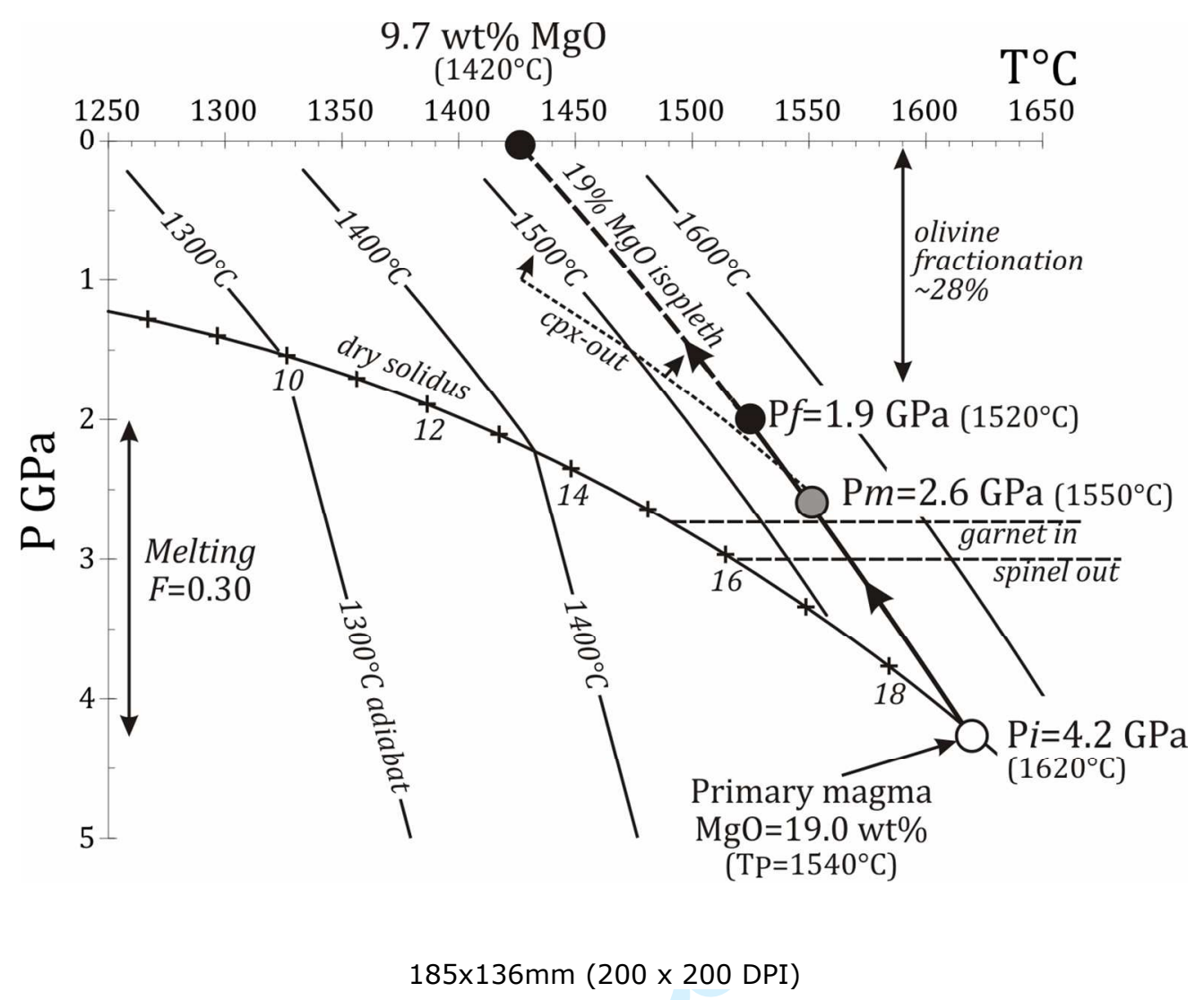

http://www.petrology.oupjournals.org/ 

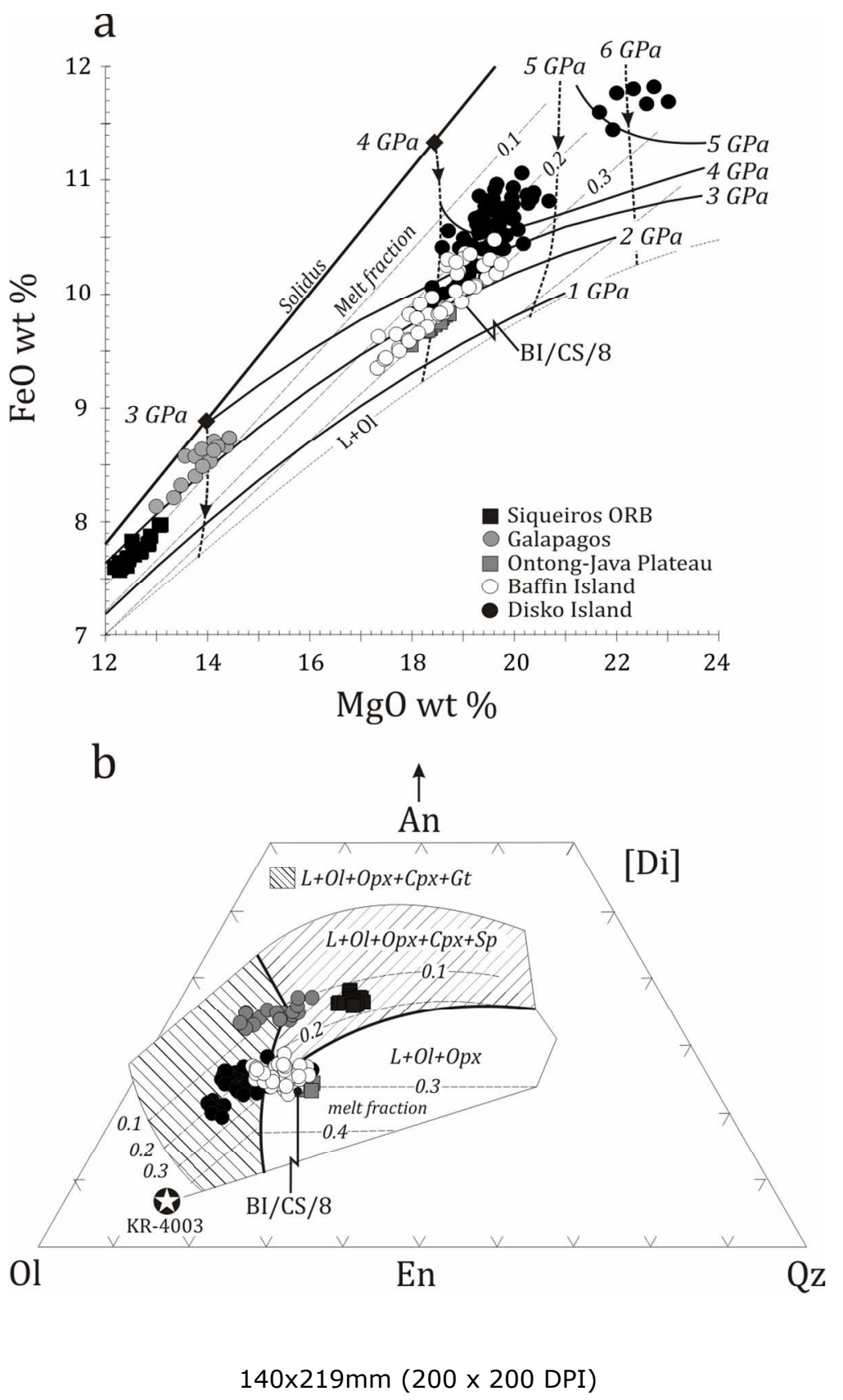


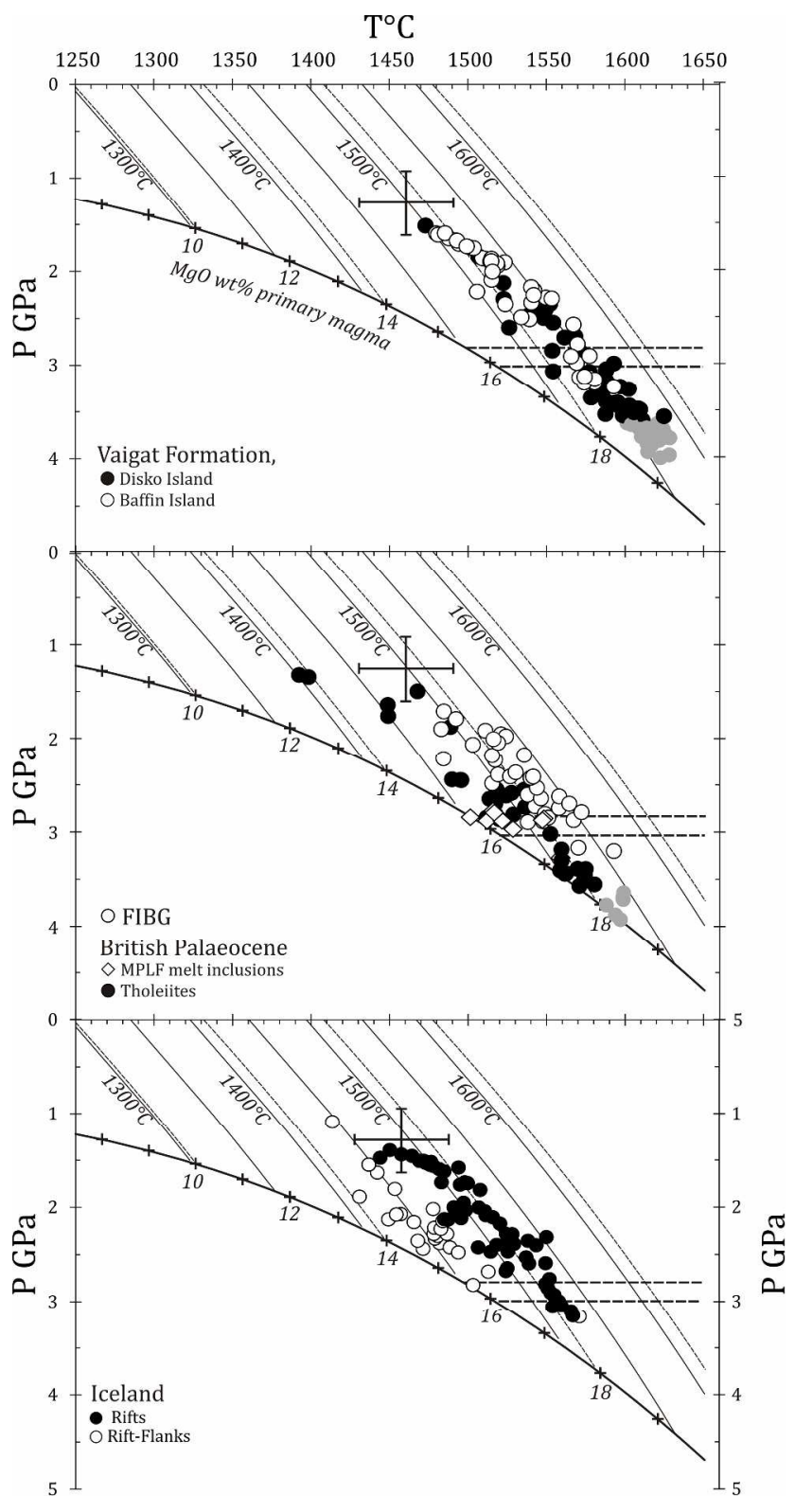

$183 \times 350 \mathrm{~mm}(300 \times 300 \mathrm{DPI})$ 


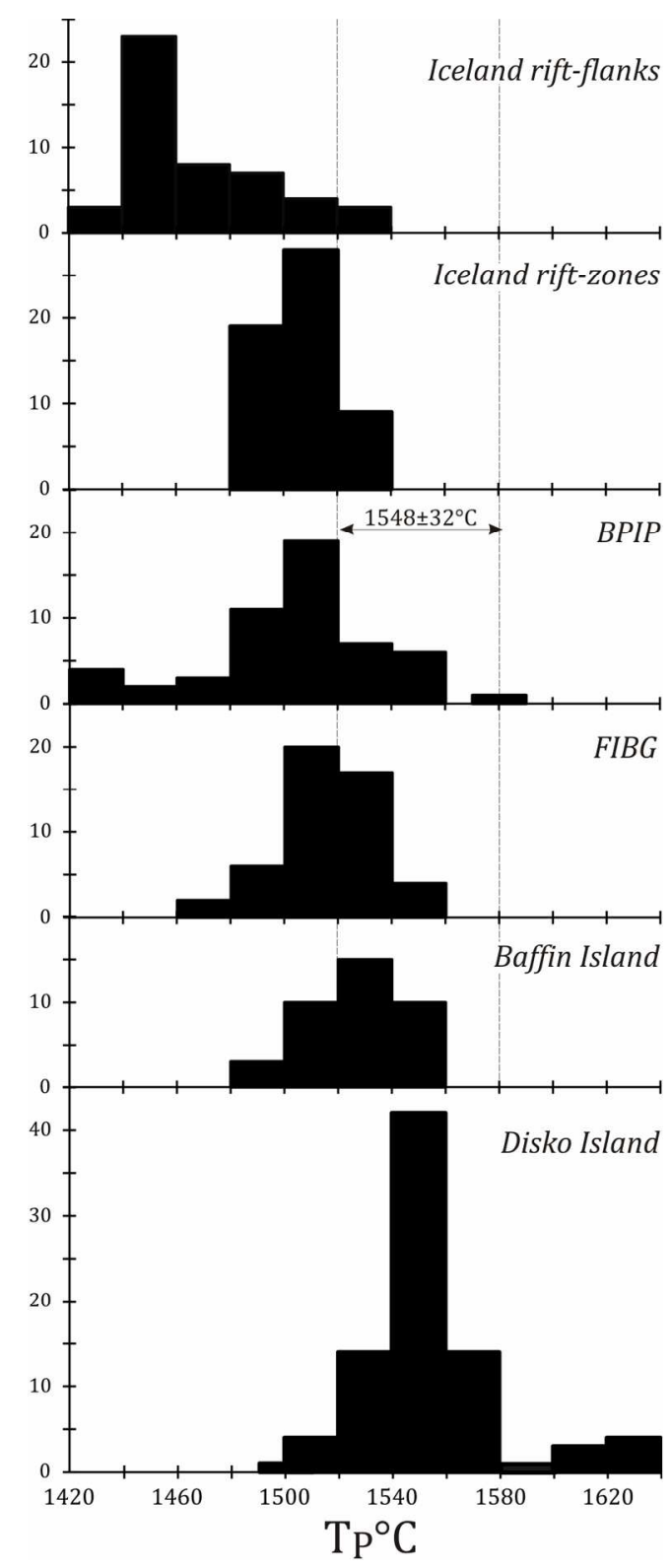

$113 \times 276 \mathrm{~mm}(200 \times 200 \mathrm{DPI})$ 


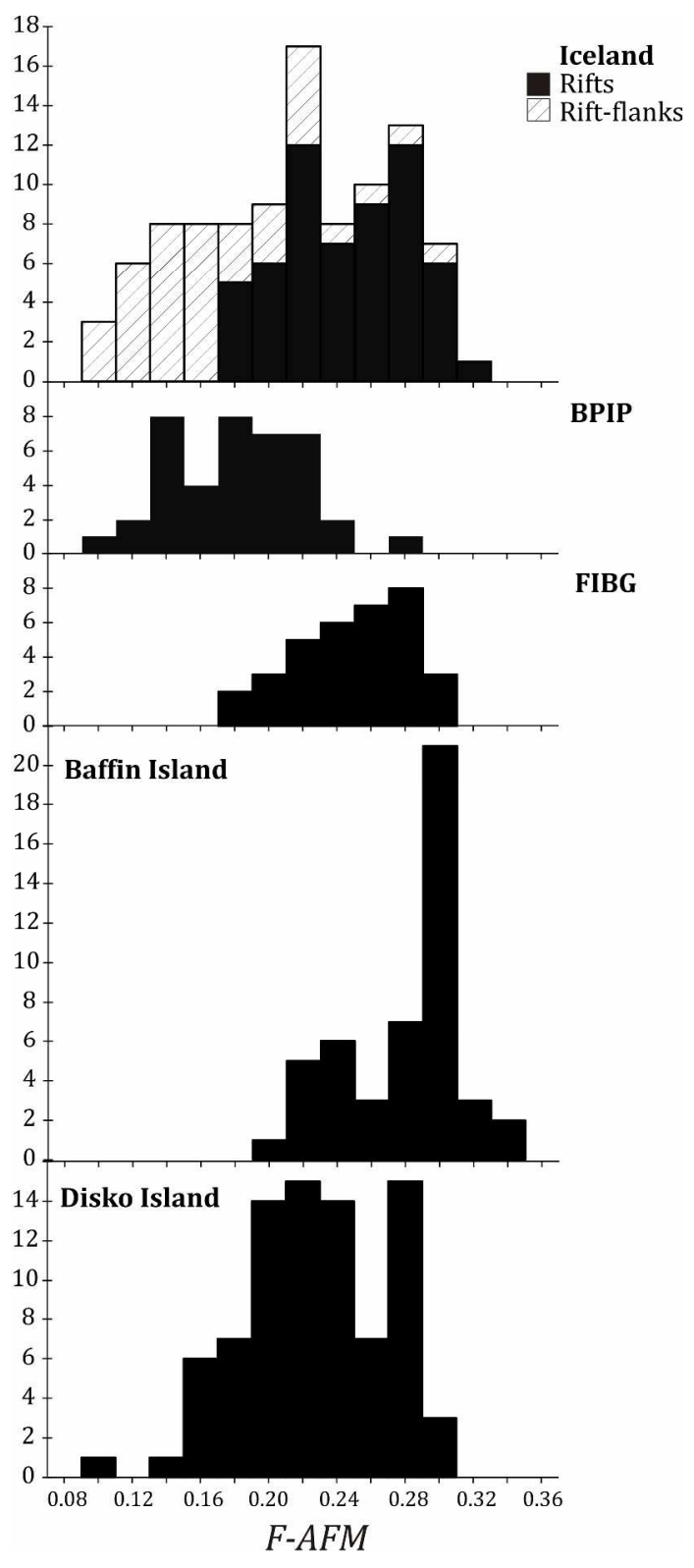

$151 \times 346 \mathrm{~mm}(300 \times 300$ DPI $)$ 


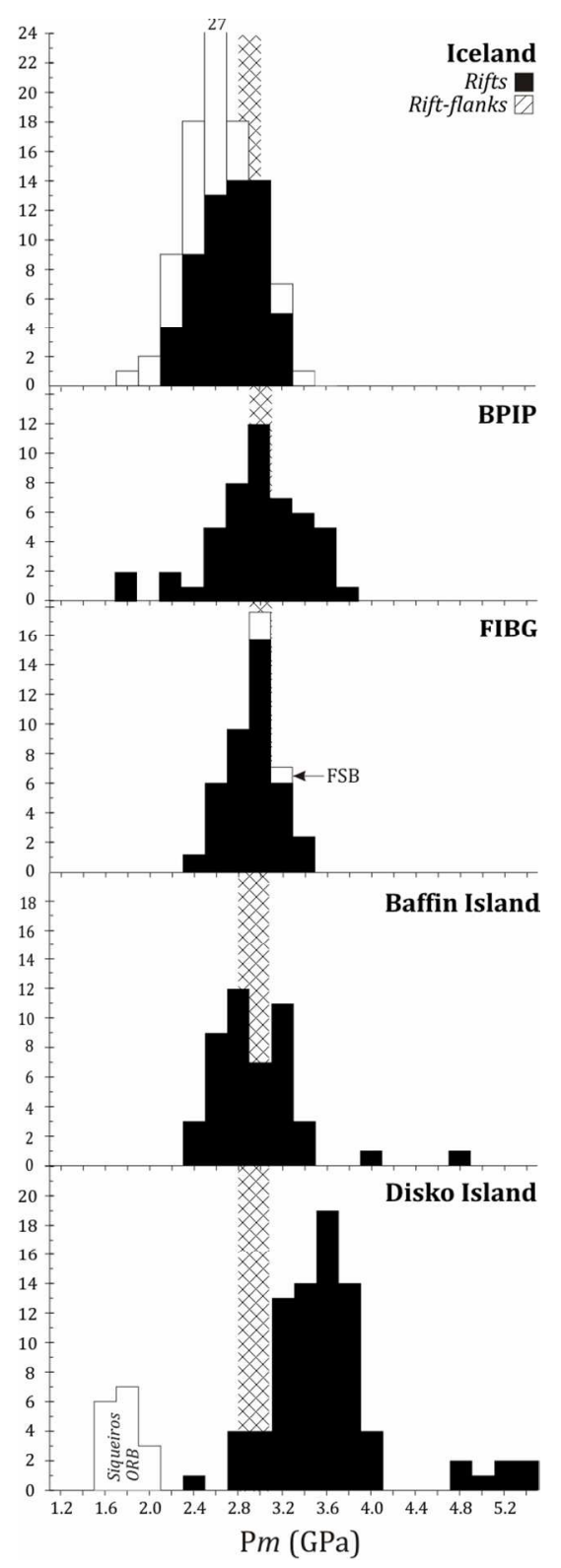

$72 \times 212 \mathrm{~mm}(200 \times 200 \mathrm{DPI})$ 


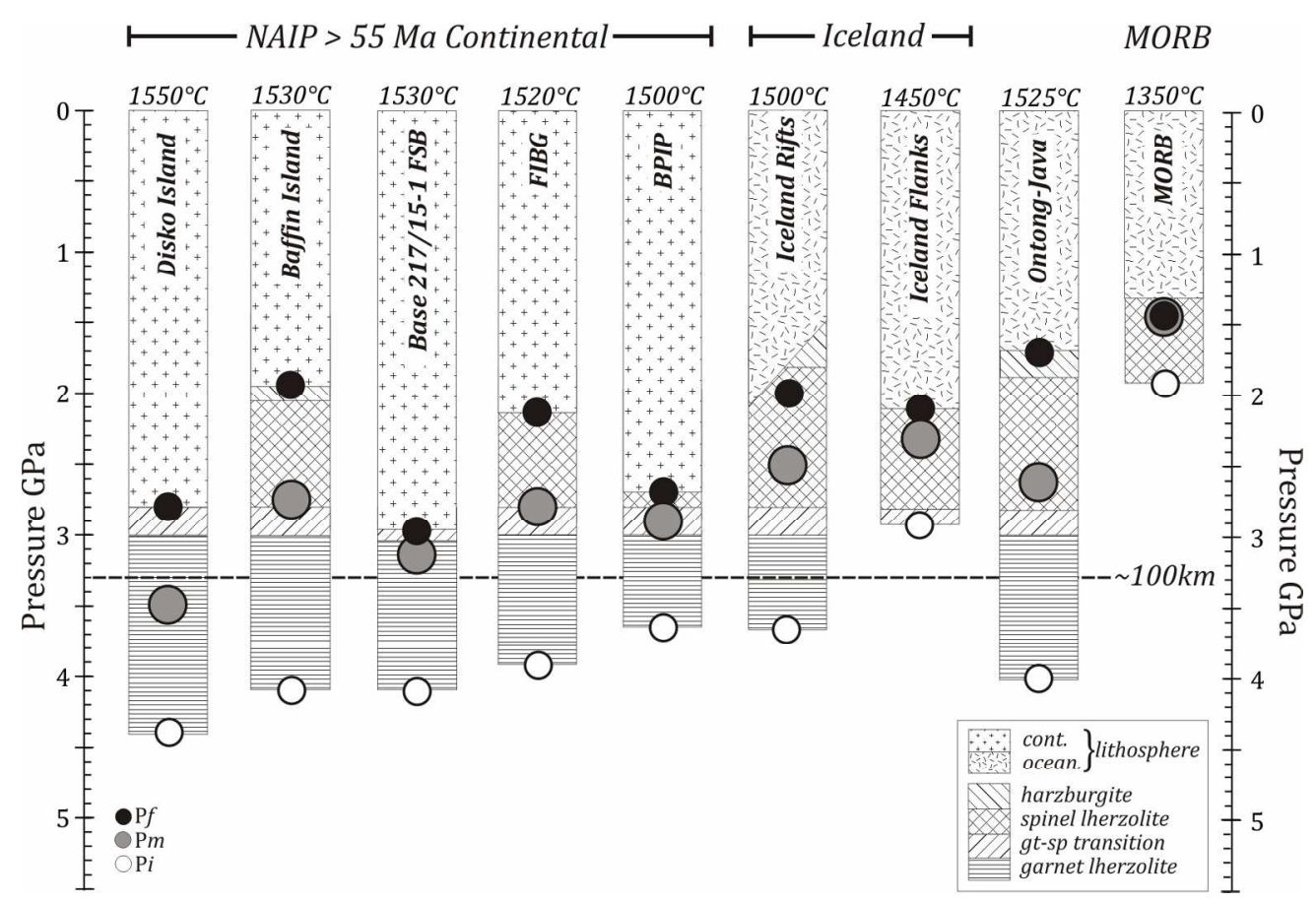

$240 \times 163 \mathrm{~mm}(200 \times 200$ DPI $)$ 


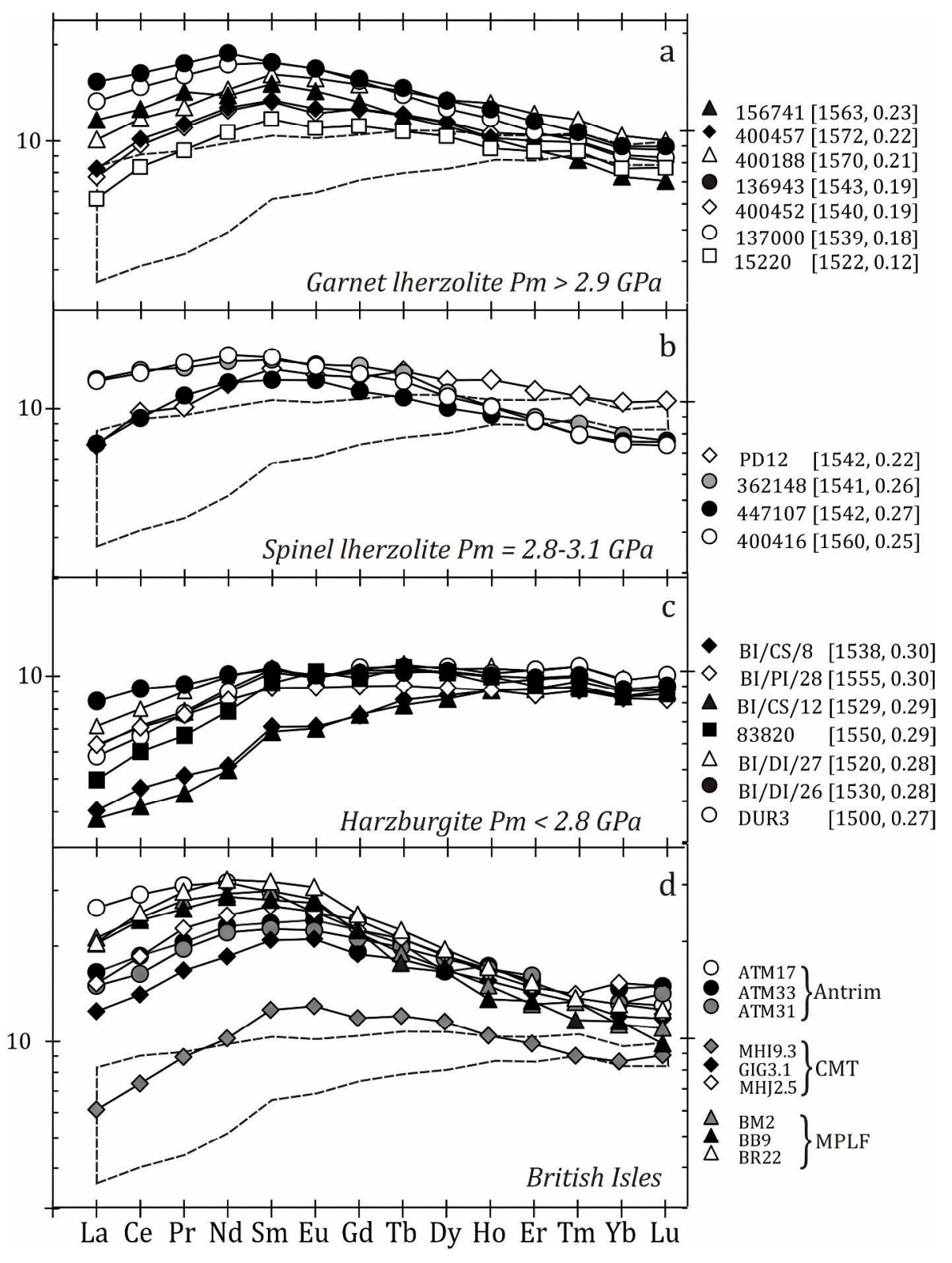

$233 \times 309 \mathrm{~mm}(300 \times 300 \mathrm{DPI})$ 


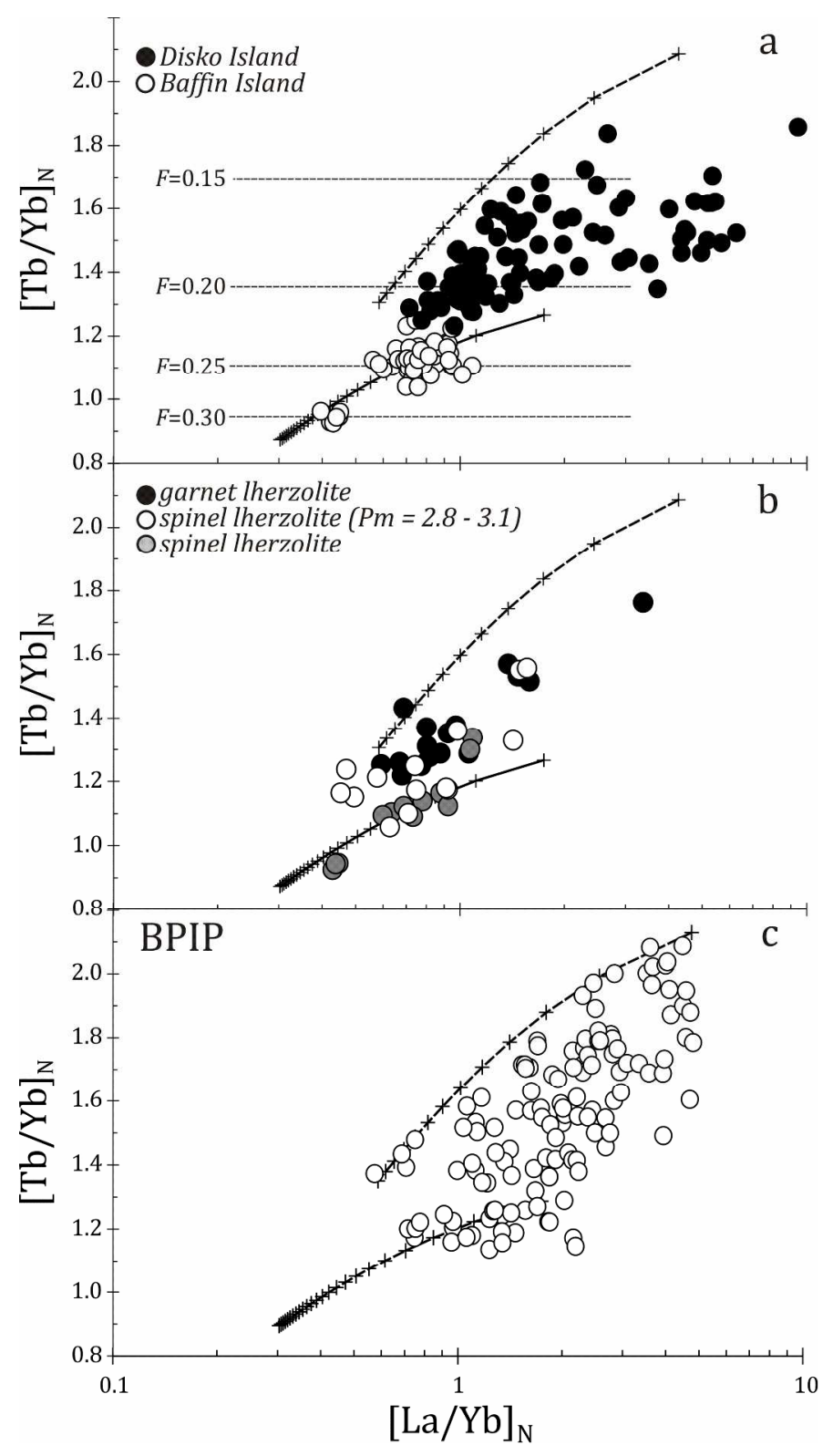

$163 \times 291 \mathrm{~mm}(300 \times 300 \mathrm{DPI})$ 
Table 1.TP, MgO and Mean melting column dimensions for NAIP primary magmas.

\begin{tabular}{|c|c|c|c|c|c|c|c|c|c|}
\hline Location & Subgroup & $n$ & $\operatorname{MgO}(w t \%)$ & $\mathbf{T}_{\mathbf{P}}{ }^{\circ} \mathbf{C}$ & $\mathbf{T}_{\mathrm{P}}{ }^{\circ} \mathrm{C}$ range & Pi (GPa) & Pf (GPa) & FAFM & $\begin{array}{c}\text { Pm } \\
\text { (GPa) }\end{array}$ \\
\hline \multicolumn{2}{|c|}{ Faroe Islands Basalt Group } & 34 & $18.3 \pm 1.4$ & $1519 \pm 36$ & $1469-1551$ & $3.9 \pm 0.6$ & 2.4 & $0.23 \pm 0.06$ & $2.8 \pm 0.4$ \\
\hline \multicolumn{2}{|c|}{ Faroe-Shetland basin (217/15-1) } & 3 & $17.1-18.9$ & $\sim 1530$ & $1510-1549$ & $\sim 4.0$ & 3.1 & $\sim 0.17$ & $\sim 3.2$ \\
\hline \multirow{2}{*}{ East Greenland } & $<1500^{\circ} \mathrm{C}$ & 5 & $15.6-16.3$ & $\sim 1460$ & $1451-1468$ & $\sim 2.9$ & 2.3 & $\sim 0.20$ & $\sim 2.2$ \\
\hline & $>1500^{\circ} \mathrm{C}$ & 14 & $19.0 \pm 1.3$ & $1539 \pm 34$ & $1508-1553$ & $4.3 \pm 0.7$ & 1.8 & $0.28 \pm 0.10$ & $2.3 \pm 0.8$ \\
\hline BPIP & Whole rocks & 45 & $17.7 \pm 2.6$ & $1504 \pm 64$ & $1451-1563$ & $3.6 \pm 1.0$ & 2.7 & $0.16 \pm 0.10$ & $2.9 \pm 0.6$ \\
\hline \multicolumn{2}{|c|}{$\begin{array}{l}\text { Mull Plateau Lava Formation melt } \\
\text { inclusions }\end{array}$} & 6 & $15.8-16.8$ & $\sim 1480$ & $1455-1482$ & & & & \\
\hline $\begin{array}{l}\text { Disko Island } \\
\text { Vaigat Formation }\end{array}$ & $\mathrm{T}_{\mathrm{P}}<1600^{\circ} \mathrm{C}$ & 73 & $19.6 \pm 2.0$ & $1548 \pm 32$ & $1513-1581$ & $4.6 \pm 1.2$ & 2.8 & $0.21 \pm 0.08$ & $3.5 \pm 1.1$ \\
\hline $\begin{array}{l}\text { Disko Island } \\
\text { Vaigat Formation }\end{array}$ & $\mathrm{T}_{\mathrm{P}} \geq 1600^{\circ} \mathrm{C}$ & 7 & $21.7-23.0$ & $\sim 1620$ & $1606-1639$ & $5.9-7.0$ & & $\geq 0.3$ & $>3.5$ \\
\hline $\begin{array}{l}\text { Baffin Island } \\
\text { Vaigat Formation }\end{array}$ & & 46 & $18.7 \pm 1.8$ & $1532 \pm 48$ & $1496-1557$ & $4.2 \pm 1.0$ & 2.1 & $0.26 \pm 0.06$ & $2.8 \pm 0.8$ \\
\hline \multicolumn{2}{|c|}{ Vaigat Formation melt inclusions (Baffin) } & 23 & $18.8 \pm 0.8$ & $1533 \pm 22$ & $1507-1551$ & & & & \\
\hline \multicolumn{2}{|l|}{ Iceland Rift Zones } & 57 & $17.8 \pm 1.4$ & $1509 \pm 32$ & $1475-1525$ & $3.7 \pm 0.6$ & 2.1 & $0.23 \pm 0.08$ & $2.6 \pm 0.6$ \\
\hline \multicolumn{2}{|l|}{ Iceland Rift flanks } & 20 & $15.7 \pm 1.0$ & $1453 \pm 28$ & $1423-1489$ & $2.9 \pm 0.4$ & 2.1 & $0.14 \pm 0.12$ & $2.3 \pm 0.6$ \\
\hline
\end{tabular}

